Лард С. ${ }^{1}$

\title{
Обзор систем торговых преференций для беднейших стран
}

Проанализировано оказание помощи беднейшим странам с целью повышения эффективности их торговых операций, осуществляемых на семи приоритетных рынках (Канады, Китая, Европейского Союза, Индии, Японии, Южной Кореи и США - посредством предоставления им преференциального режима доступа на указанные рынки). Данная проблема рассмотрена не только в страновом аспекте, но и с точки зрения охвата производимой продукции, ограничений по отдельным программам преференций, оценки стоимости программ помощи, включая потенциал для внесения улучшений, и потенциальных последствий от завершения Доха-раунда ВТО. Сформулированы некоторые предложения по программам помощи, чтобы они способствовали большему вкладу в сферу торговли НРС, в ускорение их экономического развития.

Ключевые слова: НРС, торговые преференции, бесквотный и беспошлинный доступ на рынок, программы помощи развитию.

\section{Введение}

Такие великие экономисты, как Д. Рикардо, А. Смит, Д.С. Милль, А. Маршалл и др., давно осознали огромное значение торговли для экономического развития. Торговля была определена как «движущая сила развития» [2] и как «слуга развития» $[1]^{2}$, что было признано в ГАТТ и позже во многих правовых документах ВТО, включая решение Конференции министров 1993 г. «О мерах в пользу НРС», и в более поздних текстах.

Декларация тысячелетия Организации Объединенных Наций также выдвинула на первый план важность торговли для экономического развития (цель 8) в стратегии «Цели развития Тысячелетия», призывающую к разработке «глобального партнерства для развития». На саммите G7 в 1996 г. Генеральный директор ВТО Ренато Руджеро заявил о своем намерении добиться беспошлинного и свободного от квот доступа на рынки для НРС.

1 Лард Сэм - в разнье годь ведущий экономист ЮНКТАД, Всемирного банка и ВТО.

2 Взаимосвязь торговли и развития является комплексной. Этот вопрос активно обсуждается во многих работах. 
Предложение было в основном подтверждено первой Конференцией министров ВТО, проведенной в Сингапуре позже в том же самом году ${ }^{1}$.

Целью Декларации тысячелетия ООН также было удовлетворение особых потребностей НРС (НРС), в том числе путем беспошлинного и неквотируемого доступа на рынки практически для всего их экспорта. Эта идея впоследствии стала ключевой проблемой, обсуждавшейся в рамках Брюссельской программы действий в 2001 г. В ней было отмечено, что «торговля будет тем, на что все больше будут опираться слаборазвитые страны при генерировании ресурсов для финансирования экономического роста и развития, идущих в дополнение к уже имеющимся ресурсам, полученным в рамках программы «официальной помощи на цели развития» и от потоков частного капитала». Брюссельская программа действий также привлекла внимание к тому факту, что участие НРС в международной торговле было сильно ограничено многими факторами, особенно ограничениями со стороны спроса и предложения, а также неблагоприятными условиями доступа на рынки, в частности продуктов, представляющих наибольший интерес для экспортеров.

Данная статья показывает, что за прошлое десятилетие были достигнуты важные улучшения в сфере торговли и общеэкономической деятельности НРС. Например, ЮНТКАД [3] отметил, что недавние высокие показатели роста экспорта были ключевым двигателем устойчивого роста их ВВП. Однако экономическая деятельность отдельных стран различна. Кроме того, структура экспорта НРС остается сконцентрированной на ограниченном количестве сырьевых товаров и трудоемком неквалифицированном производстве. Несколько факторов способствовали прогрессу, достигнутому НРС в последние годы, включая открытие природных ресурсов и улучшение адресной помощи в сфере торговли. Несмотря на то, что оценить масштаб, в рамках которого льготы привели к достижению большей экономической эффективности НРС, сложно эти льготы так или иначе оказали положительное прямое воздействие на их экономики. Косвенно они также помогли создать климат, в котором инвестиции в сферу торговли начинают приносить больший доход.

В то время как развитые страны остаются все еще главными рынками сбыта для экспорта из НРС, развивающиеся экономики стали главным пунктом назначения для их экспорта полезных ископаемых, топлива, меди, дерева, хлопка и некоторых продуктов питания, включая овощи и семена маслич-

1 В 14 Деклараиии Сингапурской министерской конферениии отмечается: «Мы сохраняем озабочен-ность проблемами наименее развитьх стран и согласились принять план действий, включая положе-ния о позитивных мерах, например, о предоставлении беспошлинного режима на автономной основе, направленных на расширение их способности использовать возможности, которые предоставляет торговля...». 
ных растений. Мировые цены на эти товары росли в течение всего прошлого десятилетия. Развитые страны предлагают НРС почти полностью беспошлинный и неквотируемый доступ на свои рынки, есть исключения, особенно в США. Доступ может быть увеличен через содействие в повышении производительности, чтобы соответствовать стандартам и совершенствуемым правилам происхождения товара, особенно в свете размывания преференций, которое, вероятно, произойдет по завершении Доха-Раунда. В то же время более крупные развивающиеся страны могут значительно расширить доступ к рынку для НРС. (Преференции этих стран менее вероятно будут затронуты связанной с Дохой эрозией, о чем речь пойдет ниже.)

Преференции также должны учитываться как часть двухаспектного подхода к помощи малоразвитым странам на пути к улучшению соотношения спроса и предложения. Лучший доступ на рынок через неквотируемые и беспошлинные программы помогает повысить спрос путем снижения цен на экспорт слаборазвитых стран. Но это должно быть дополнено усилиями, направленными на увеличение предложения НРС и производительных возможностей, а также торговой инфраструктуры через помощь для развития торговли, что частично включает поддержку роли частного сектора, а также и привлечение иностранных и внутренних инвестиций. Улучшенные возможности торговли для слаборазвитых стран через беспошлинные и неквотируемые схемы могут способствовать этим усилиям на стороне предложения.

Однако прежде чем прийти к исследованию полного покрытия схем на семи отобранных рынках (Канада, Китай, Европейский Союз, Индия, Япония, Корея и США), включая показатели по секторам и определенным малоразвитым странам, познакомимся с историей и правовой основой.

\section{1. История, обоснование и правовая основа беспошлинных и бесквотных схем преференциального доступа}

\section{1. История и обоснование}

Идею о предоставлении торговых преференций развивающимся странам впервые высказали в своих работах Р. Пребиш и Х. Зингер в 1960-х годах, подкрепив этим общую систему преференций. Аргументы были существенными: режим наибольшего благоприятствования (РНБ) не обеспечивал равенство с отечественными производителями или региональными торговыми партнерами, если не был нулевым. Кроме того, данный режим не принимал во внимание неравенство в экономических структурах и уровнях развития. А поскольку переговоры проводились на основе взаимности и принципа наиболее благоприятствуемой нации, экспорт развивающихся стран продолжал сталкиваться с высокими тарифами, преференции же рассматривались как вспомогательный фактор для преодоления этих недостатков. 
Впоследствии предложения Пребиша были приняты в качестве принципа в работе ЮНКТАД II в Нью-Дели в 1968 г. Участники Конференции согласились, что «целями обобщенной, необратимой (односторонней), справедливой системы предпочтений в пользу развивающихся стран должны быть: а) увеличение их доходов от экспорта; б) для содействия индустриализации и в) ускорении темпов экономического роста. Было также признано, что «особые предпочтения нужно предоставить странам, обладающим наименьшим преимуществом». Однако в первые годы главной целью было развитие схем общих преференций без тщательно продуманных планов по предоставлению особых предпочтений НРС, хотя они, возможно, извлекли выгоду из специальных положений по продуктам ремесленного производства и избежали различных запретов, что будет рассмотрено далее.

Главный прорыв в развитии специальных условий для НРС на более общей основе произошел, когда первая Министерская конференция ВТО в 1996 г. в основном подтвердила предложение Генерального директора Руджеро стремиться к беспошлинному и неквотируемому доступу их экспорта на рынки развитых стран. Предложение принесло плоды, когда в подготовительном периоде к третьей Конференции по НРС в Брюсселе торговый представитель ЕС Паскаль Лами объявил о намерении ЕС предоставить беспошлинный и неквотируемый доступ для большинства товаров, произведенных в указанных странах. В феврале 2001 г. Европейская комиссия приняла постановление № 416/2001 по реализации программы «Все, кроме оружия», предоставляющей беспошлинный и неквотируемый доступ для импорта всех продуктов из НРС, кроме оружия и боеприпасов (хотя количественные ограничения были введены на бананы, сахар и рис в течение ограниченного периода) ${ }^{1}$. Принятая в 2001 г. в Брюсселе на третьей Конференции ООН по НРС (НРС-3) программа действий для НРС включала, среди прочего, обязательство партнеров из развитых стран улучшить преференциальный доступ к рынку для НРС за счет как беспошлинного и неквотируемого доступа к рынку всех их товаров, так и упрощения правил происхождения товаров.

Кроме того, Брюссельская программа действий включала обязательства гарантировать НРС извлечение выгоды из возросшего доступа к рынкам, а также из реализации многосторонних программ, например, таких как Интегрированная программа технической помощи НРС в области торговли, для того чтобы усовершенствовать производство и экспортные мощности. В указанной программе содержалось и обязательство помощи НРС участвовать в установлении международных стандартов, достичь и придержи-

1 Это решение было затем инкорпорировано в Council Regulation (EC) № 2501/2001, предусматриваю-щей специальные меры в интересах НРС, которые действуют неограниченное время и не должны из-меняться в рамках пересмотров общей системы преферениий. 
ваться этих стандартов. В Брюсселе было признано, что НРС нуждаются в помощи в борьбе с колебаниями цен на товары, в содействии в развитии их производительных мощностей, дифференцировании товаров и нахождении ниш на рынке. Особое внимание было уделено укреплению местных банковских систем и развитию других финансовых услуг, для того чтобы сделать их конкурентоспособными, а также помощи в увеличении их производственного потенциала услуг с высоким спросом, особенно в туризме, воздушном транспорте и других выгодных для НРС областях.

Несмотря на то, что на IV Конференции ООН по НРС, проводимой в Стамбуле в 2011 г., была выражена некоторая озабоченность по поводу достижений в реализации Брюссельской программы действий, широкомасштабные задачи НРС были подтверждены. К ключевым задачам отнесены проблемы, связанные с торговлей, сельским хозяйством, предметами потребления, продовольственной безопасностью и мобилизацией ресурсов. В сфере торговли делегаты Конференции согласились на «серьезную работу для создания благоприятных условий доступа к рынку для всех продуктов, производимых в НРСах, включая своевременное внедрение беспошлинного, неквотируемого доступа к рынку на длительной основе для всех НРС с простыми, прозрачными и предсказуемыми правилами происхождения товаров и сокращение или устранение дискреционных или неоправданных нетарифных барьеров и других сдерживающих торговлю мер.

\section{2 Правовая основа и требования по нотификациям (уведомлениям)}

Чтобы общая система преференций (ОСП) стала юридически готовой к эксплуатации, участники (договаривающиеся стороны) ГАТТ в июне 1971 г. решили отказаться от положений ст. I ГАТТ сроком на десять лет. Это было необходимо, чтобы разрешить предоставлять преференциальный таможенный режим продуктам, производимым в развивающихся странах. Наконец, после завершения в Токио Раунда в 1979 г. договаривающиеся стороны приняли решение о дифференцированном и более благоприятном режиме, взаимности и более полном участии развивающихся стран (развязывающая оговорка), которое обеспечило правовую основу для предоставления торговых преференций - тарифных и нетарифных мер развитыми договаривающимися сторонами в пользу развивающихся стран, а также специального режима для НРС в контексте любых общих или определенных мер в пользу развивающихся стран ${ }^{1}$.

1 Развязывающая оговорка не предоставляет основу для невзаимных и селективных преферениий, как, например, преференииальное соглашение ЕС - страны АКТ (Африки, Карибского бассейна и Тихого океана) или соглашения между США и Канадой и странами Карибского бассейна. Такие соглашения обеспечиваются ограниченным по времени освобождением от обязательств (вейвером) по ст. I ГАТТ и требуют решения о продлении. 
Следует отметить, что развязывающая оговорка не обеспечивает юридическое покрытие для предоставления односторонних преференций развивающимися странами в пользу НРС. Юридическая основа для этого была создана ВТО принятием от 15 июня 1999 г. документа WT/L/304, разрешившего отказ от обязательств (вейвер, англ. waiver) в соответствии с положениями $\$ 3$ ст. IX Соглашения об учреждении ВТО. Действие отказа от обязательств было продлено Решением Генерального совета в 2009 г. (документ WT/L/759) еще на десять лет по запросу Бразилии, Китая, Индии и Республики Корея (документ G/C/W/620)ํ․․

Развязывающая оговорка требует, чтобы члены ВТО зарегистрировали введение, модификацию или отказ от преимуществ в рамках общей преференции и предоставили любую другую информацию, которую они считают соответствующей. Это относится только к развитым странам-участницам. Такого требования для развивающихся стран, использующих привилегии НРС по существующему или предшествующему отказу, не существует. Однако, несмотря на то, что развитые страны-участницы представили ВТО обширные уведомления, нет уверенности в том, что они достоверны. Например, в октябре 2001 г. ВТО отметила, что «разработка исследования функционирования схем общей системы преференций Секретариатом ВТО была осложнена отсутствием всесторонних и легкоприменимых уведомлений участников и пробелов в доступных данных на применении преференций схем общей системы преференций в целом» (документ WT/ COMTD/W/93).

\section{2. Охват стран, товары и объемы торговли}

\section{1. Обзор отобранных схем преференций}

В результате последовательного расширения в последние годы программ преференций в пользу НРС их охват стал более обширным. Однако есть много исключений в отношении охвата в отношении как стран (главным образом по политическим причинам), так и чувствительных к импорту продуктов.

Таблица 1 показывает охват, размер преференций и основные источники информации для отдельных стран с учетом дополнительных данных по Китаю и Корее, а табл. 2 представляет краткий обзор основных изъятий в рамках программ преференций промышленно развитых стран в 2010 г. на основе данных ВТО.

1 В то же время развязываюшая оговорка разрешает ассиметричные взаимные преберениии между раз-виваюшимися странами, включая НРС, с ограниченной сферой применения и длительньми переход-ными периодами. 


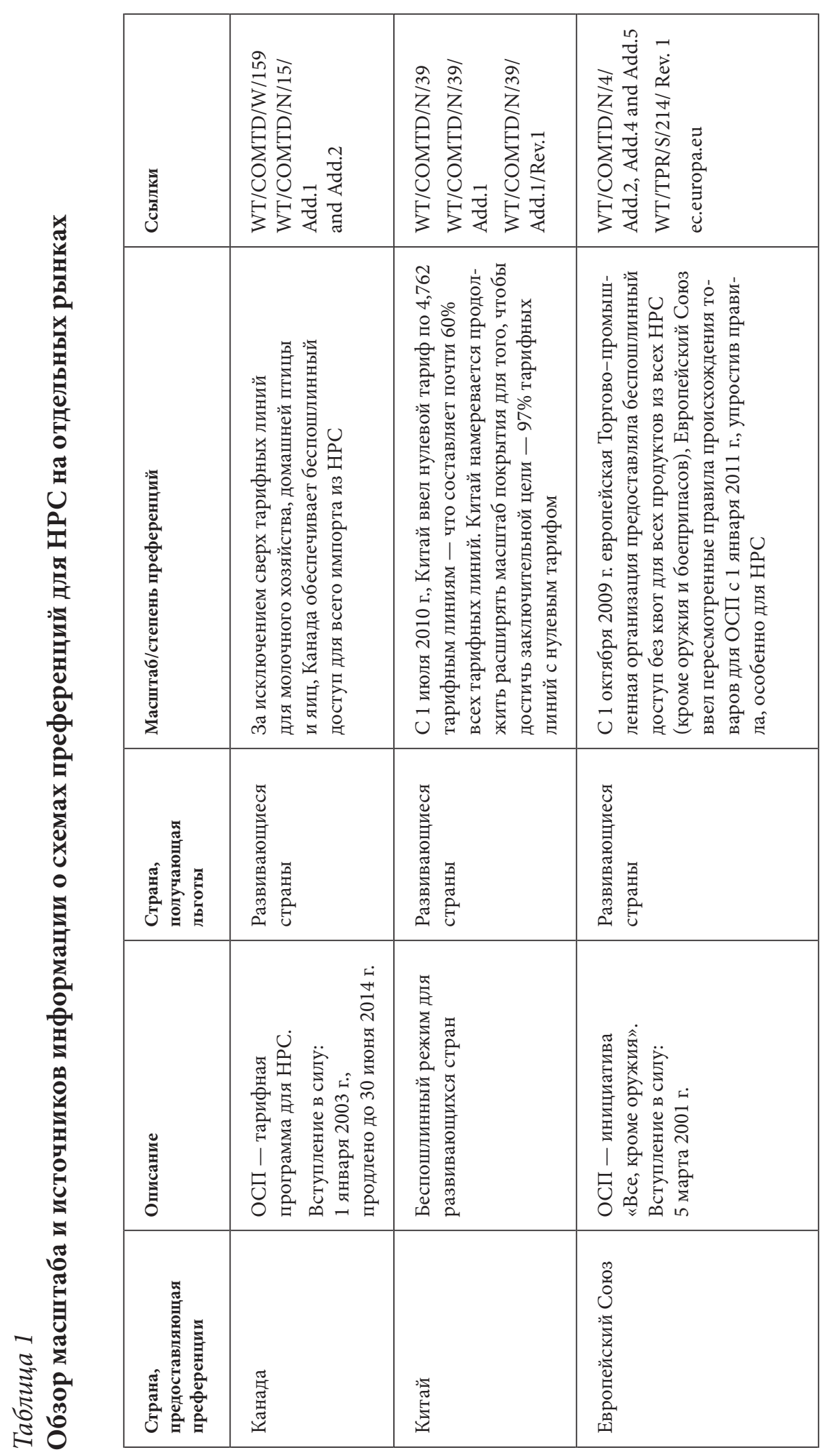




\begin{tabular}{|c|c|c|c|c|}
\hline U. & 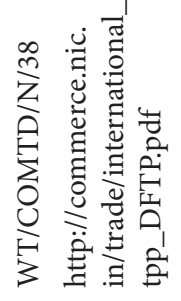 & 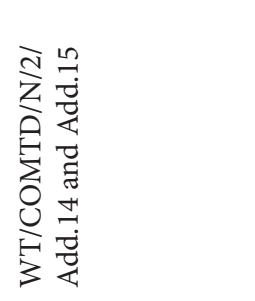 & 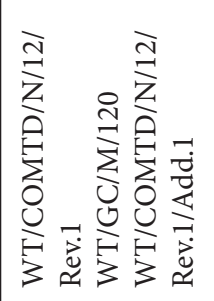 & 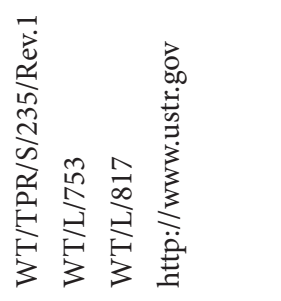 \\
\hline 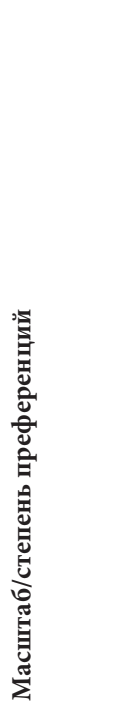 & 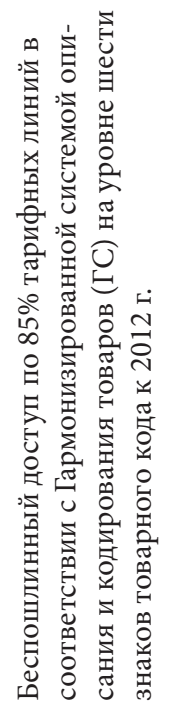 & 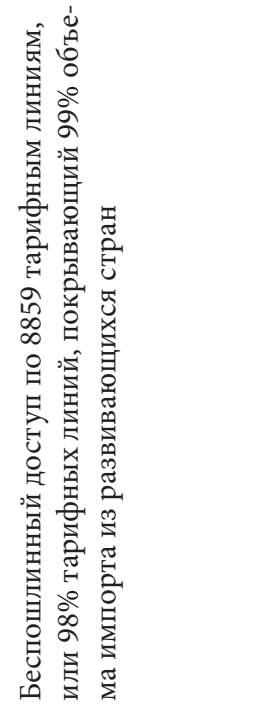 & 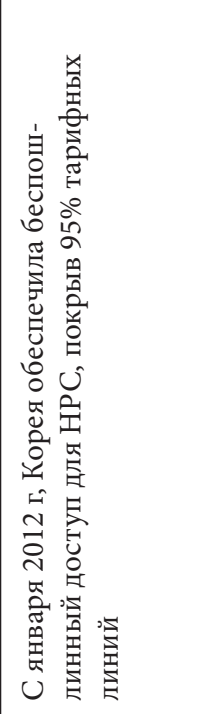 & 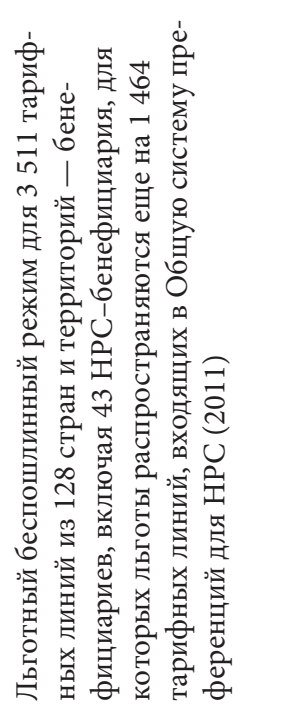 \\
\hline 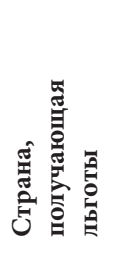 & $\begin{array}{l}\text { U } \\
\text { 至 }\end{array}$ & $\begin{array}{l}\text { U } \\
\text { 蒫 }\end{array}$ & 哯 & 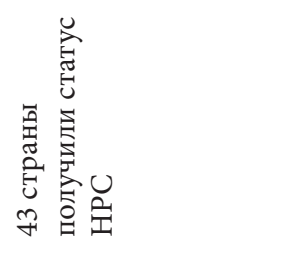 \\
\hline 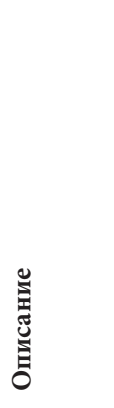 & 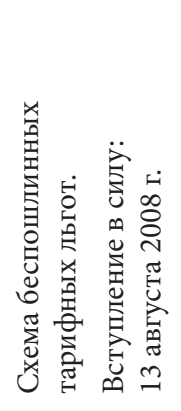 & 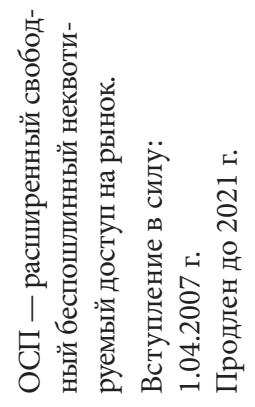 & 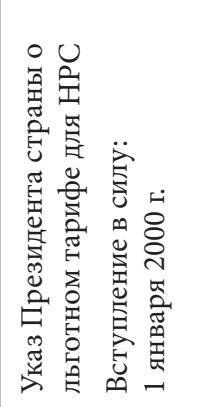 & 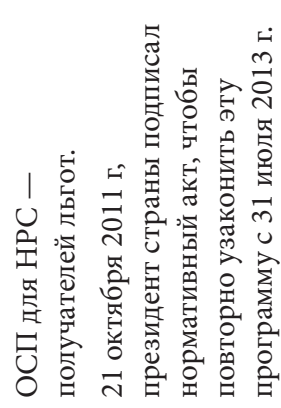 \\
\hline 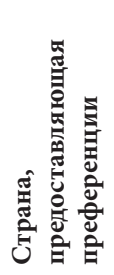 & 密 & 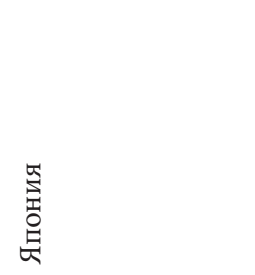 & 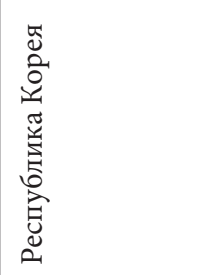 & 岁 \\
\hline
\end{tabular}




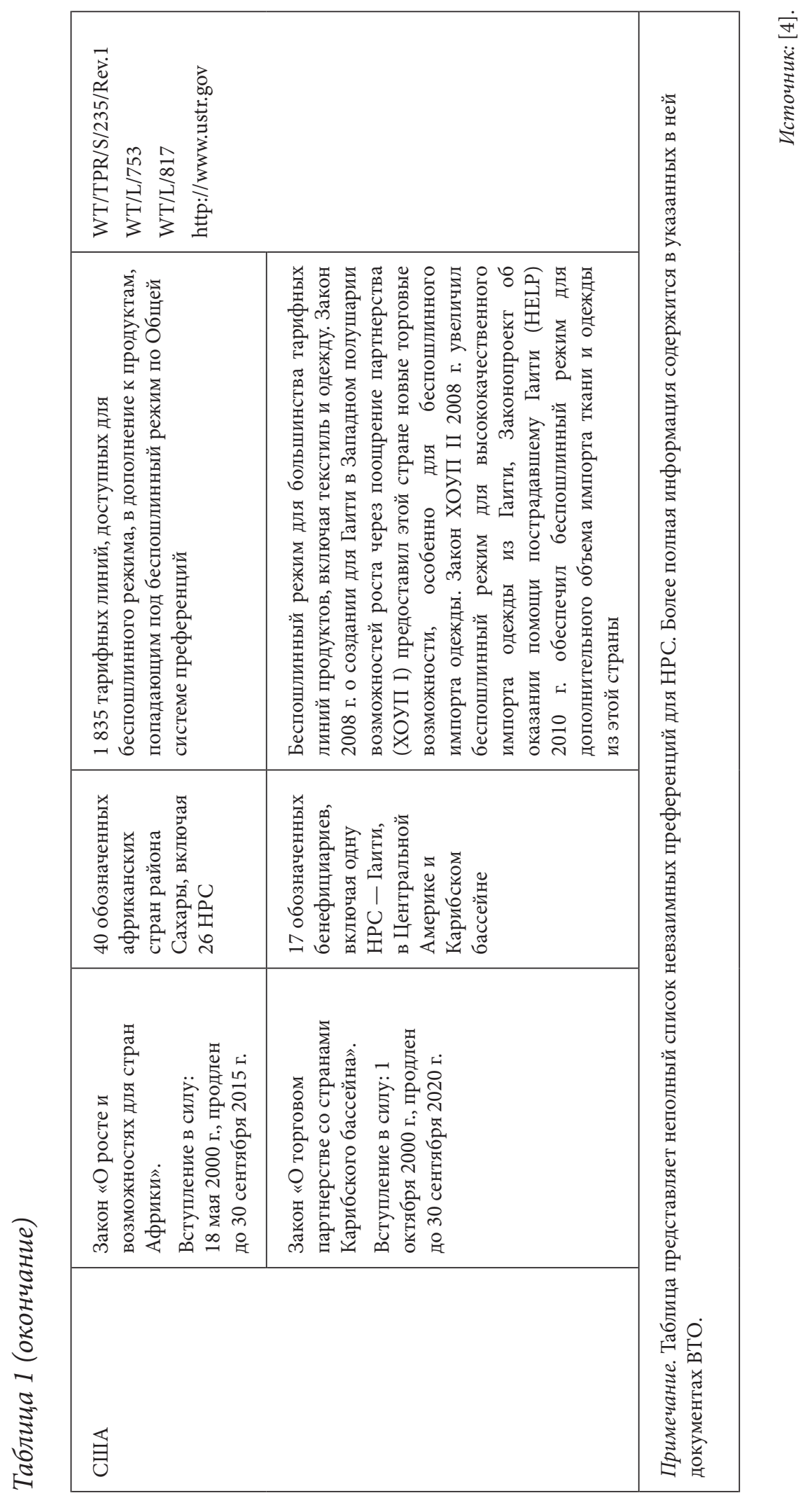




\section{Таблица 2}

\section{Беспошлинный и неквотируемый доступ к схемам Общей системы преференций развитых стран}

\begin{tabular}{|l|l|l|}
\hline Страна & $\begin{array}{l}\text { Охват беспошлинным режимом } \\
\text { и исключения* }\end{array}$ & $\begin{array}{l}\text { Число подлежащих } \\
\text { налоговому обложению } \\
\text { тарифных линий } \\
\text { (национальные тарифные } \\
\text { линии) }\end{array}$ \\
\hline Канада & $\begin{array}{l}98,8 \% \text { (молочное хозяйство, яйца и } \\
\text { домашняя птица) }\end{array}$ & 102 \\
\hline $\begin{array}{l}\text { Европейский } \\
\text { Союз }\end{array}$ & \begin{tabular}{l} 
99,8\% (оружие и боеприпасы) \\
\hline Япония
\end{tabular} & $\begin{array}{l}\text { 98,2\% (рис, сахар, рыбопродукты, } \\
\text { изделия из кожи) }\end{array}$ \\
\hline США & $\begin{array}{l}82,4 \% \text { (молочные продукты, сахар, } \\
\text { какао, изделия из кожи, хлопка, } \\
\text { швейные изделия и одежда, текстиль } \\
\text { и текстильные изделия, обувь, часы и } \\
\text { т,д, }\end{array}$ & \\
\hline
\end{tabular}

Источник: данные WTO.

В целом предоставляющие привилегии страны не создавали сложных правил для ограничения их применения НРС, так как в этом не было потребности. С одной стороны, развивающиеся страны не представляют значительной угрозы производителям на крупнейших рынках ввиду того, что их возможности поставок ограниченны. С другой стороны, привилегии развивающимся странам предоставляются в одностороннем порядке, и для их аннулирования ВТО не требует ничего, кроме уведомления об отказе от предоставления привилегий. Исключение стратегических материалов (чувствительных продуктов) и право аннулировать предпочтения без сложных процедур ВТО объясняют, почему только у нескольких из рассмотренных рынков есть тщательно продуманные меры защиты рынка или меры по избирательному применению преференций. В США и ЕС, например, такие меры кажутся более предназначенными для общей системы бенефициариев в целом, а не для НРС. Дополнительная защита возможна за счет применения сложных правил происхождения товаров, о чем пойдет речь далее, в п. 3.

Антидемпинговые меры редко применялись против импорта из развивающихся стран. Главное исключение - меры против Бангладеш, которые применяли Бразилия (джутовые мешки), Индия (свинцовые батареи) и США (магазинные полотенца). 
Нет никаких доказательств существования мер против субсидированного экспорта НРС на рынках, рассматриваемых в данной статье.

Как и все члены ВТО, семь отобранных для исследования стран могут поднять тарифы сверх таможенных пошлин РНБ в рамках обычных общих исключений (ст. XIX ГАТT), хотя меры ст. XIX могут применяться против НРС, они (эти страны) не давали повода для использования защитных мер.

Устоявшейся единой процедуры выхода из «статуса» бенефициара-НРС нет. Вопрос сглаживания переходного процесса для стран, завершающих стадию НРС, рассматривает в ООН специальная Рабочая группа открытого состава, включающая представителей различных агентств ООН и ВТО. Когда проблема была поднята на встрече Рабочей группы в феврале 2012 г., Сопредседатели выразили надежду, что рекомендации будут усовершенствованы и позволят постепенно сокращать поддержку малоразвитым странам, если нет особых причин сохранить ее для конкретной страны. После изменения статуса Мальдивы выразили заинтересованность в продолжении Европейским Союзом программ льгот «Все, кроме оружия», ссылаясь на то, что Китай сохранил для них льготы. На практике ЕС декларирует поддержку беспошлинных, неквотируемых привилегий в течение трех лет после смены категории страны.

\section{2 Основные особенности индивидуальных систем преференций ${ }^{1}$}

Канадская общая система преференций, впервые введенная 1 июля 1974 г., детально описана на сайте Агентства пограничных служб Канады. Она была модифицирована в 2000 г. с целью улучшения условий доступа на рынок для НРС путем расширения номенклатуры товаров и либерализации правил происхождения товаров. Это было доведено до сведения Комитета по торговле и развитию ВТО согласно развязывающей оговорке. Весь ассортимент товаров не подлежит обложению таможенными пошлинами и квотами, за исключением сельскохозяйственной продукции, а именно: молочных и птицеводческих продуктов. Товары, охваченные канадской системой, получают преференциальные скидки в соответствии с тарифами РНБ, которые меняются в зависимости от продукта. Ремесленные изделия, соответствующие определенным критериям, и товары, произведенные в НРС, в условиях беспошлинного режима, в основном, выигрывают.

1 Канада, ЕС и США сделали исчерпывающие нотификации своих систем преферениий и периодически их обновляю. Ххотя таких обязательств сделать нотификации у Китая, Индии и Кореи, они их предо-ставили. Лучшим источником информации является база данных ВТО по преференииальным торго-вым соглашениям, созданная в декабре 2010 г. (документ WT/L/806). 
Согласно положениям Канадского таможенного тарифа преференции могут быть устранены генерал-губернатором по рекомендации министра. Хотя критерии отмены преференций не прописаны четко, общая формулировка, касающаяся мер защиты рынка, похожа на формулировку ст. XIX ГАТТ, требующую доказательств «серьезного повреждения» или угрозы серьезного повреждения. Это не относится непосредственно к тарифам НРС, отмена которых не основывается ни на каких требованиях ВТО, за исключением предварительного уведомления. Однако если Канада поднимет тарифную ставку на импортные товары из стран с низшим уровнем экономического развития выше тарифной ставки РНБ, то будут применены стандартные меры предосторожности.

Китайская программа беспошлинного режима вступилав силу 1 июля 2010 г. ${ }^{1}$ Изначально эта программа имела меньший охват, чем другие программы, рассматриваемые в данной статье. На сегодняшний день она расширилась настолько, что Китай покрывает около 97\% своих тарифных линий. Если страна, выходила из статуса НРС, Китай переставал предоставлять им льготы, за исключением Мальдив, когда он решил продолжить вводить преференции, выходя за рамки постановлений $\mathrm{OOH}$.

Согласно уведомлению ВТО в Китае в декабре 2011 г. программа покрывала 4788 тарифных позиций (на уровне восьмизначных позиций) и насчитывала около $60 \%$ всех тарифных позиций.

Китайские данные таможенной статистики показывают, что в рамках программы импорт из НРС в 2010 г. составлял 42,2 млрд долл., что составило 97\% китайского импорта из этих стран. Китай планирует и дальше открывать свой рынок для НРС, расширяя охват программы до 97\% всех тарифных позиций ${ }^{2}$.

В Европейском Союзе программа беспошлинного импорта «Все, кроме оружия», вступившая в силу 5 марта 2001 г., была создана в соответствии с постановлением Совета ЕС в качестве усовершенствования существующей ОСП ЕС. Программа «Все, кроме оружия» - неотъемлемая составная часть всеобщих систем тарифных преференций в Европейском Союзе, охватываемых десятилетней программой (до 2015 г.). В отличие от ОСП преференции для развивающихся стран в целом и специальные правила для НРС в рамках указанной программы не ограничены по времени. Их основная задача - уменьшение нестабильности доступа к предпочитаемым рынкам.

1 WTO documents G/C/W/656/Rev.1 and WT/COMTD/N/39/Add.1/Rev.1 of 1 December 2011. По данным ВТО, Китай также с 2009 г. предоставил в одностороннем порядке преберениии некоторым товарам из 41 НРС (документ WTO/ TPR/S/230/Rev.1 of 5 July 2010). 
В 1995 г. ЕС устранил почти все количественные ограничения на импорт из НРС. Только три вида товаров не были разрешены сразу: бананы, рис и сахар. Они были разрешены поэтапно в течение пяти- и восьмилетних периодов, истекших на данный момент.

В 2011 г. ЕС провел серию изменений в основных программах, устранив преференции для ряда стран, что обосновал уровнем доходов или альтернативными преимуществами. Главной же причиной было желание сконцентрировать торговые выгоды в НРС. ЕС пояснял, что основной задачей данных изменений было повышение предсказуемости, прозрачности и стабильности ${ }^{1}$. Однако, как отмечалось, названная программа должна была стать неограниченной по времени, а не подвергаться пересмотру каждые три года. Предложения, которые будут выдвинуты в Европейском парламенте в 2014 г., «сделают процедуру покупки у НРС более простой и привлекательной для импортеров из ЕС. Более того, сделки станут более прозрачными, с более четко обозначенными юридическими основами и объективными критериями» (официальный сайт ЕС) ${ }^{2}$.

ОПС ЕС содержит специальный механизм, в соответствии с которым преференции могут быть устранены для отдельных секторов экономик стран-бенефициаров, достигших определенного уровня конкурентоспособности, что позволяет им повышать экспорт без режима тарифных преференций. Это также касается НРСП ${ }^{3}$. ЕС вводит особые временные меры для тех НРС, которые, возможно, «покинут» этот список. Так, постановление Европейского Совета ЕС № 1547/2007 от 20 декабря 2007 г. определило переходный период для исключения Республики Кабо-Верде из списка стран, получающих тарифные выгоды. Похожие меры были приняты и в отношении Мальдив.

Европейский Союз может также отменить преференции для НРС по политическим причинам. Например, Мьянма была исключена из ОПС в 1997 г. (постановление Совета № 552/97) на основании положений, которые устанавливали, что преференции могут быть отменены при определенных

1 Memo/11/284 of 10 May 2011.

2 Внутреннее мнение Еврокомиссии можно понять из ее рабочего документа «Trade as a driver of devel-opment» (Брюссель, 27 января 2012 г.), являющегося сопроводительным документом $\kappa$ «Сотmиnica-tion from the Commission to the European Parliament, the Council and the European Economic and Social Committee on trade, growth and development. Tailoring trade and investment policy for those countries most in need».

3 С деталями системы преференций ЕС можно ознакомиться на его сайте: (http://ec.europa.eu/trade/wider-agenda/development/generalised-system-of-preferences/ everything-but-arms/, a также в изданиях ЮНКТАД: UNCTAD Handbook on the EU GSP Scheme. http://www.unctad.org/gsp/.OCП действует а основе 10-летнего ииикла, чтобы учесть изменения в тор-говле. Текущий иикл начался в 2006 г. изавериится в 2015 2. 
условиях, включая использование любых форм принудительного труда (Конвенции МОТ 29 и 105).

Индийская программа беспошлинной торговли, вступившая в силу в августе 2008 г., применяется к странам, отнесенным ООН к НРС. Чтобы иметь на это право, страна обязана направить в правительство Индии письмо-обязательство и данные об официальных лицах, ответственных за выпуск свидетельств о происхождении товаров. Кроме того, Индия заключила несколько выборочных реверсивных контрактов: Южно-Азиатское соглашение о свободной торговле (SAFTA), в него вошли Бангладеш, Бутан, Мальдивы (относились к НРС до 2011 г.) и Непал, а также Азиатско-Тихоокеанское торговое соглашение, которое тоже включает Бангладеш. Однако преференции могут быть отменены в одностороннем порядке в любое время. Индия разработала правила для приостановки преференций и использования защитных мер ${ }^{1}$. Преференции могут быть отменены: а) в связи с определенными нарушениями (например, мошенничество); б) когда импорт в рамках программы значительно превышает обычный уровень производства и потенциальный объем экспорта страны, которая обладает преференциями; в) страна больше не относится к наименее развитым (после выхода из списка ООН только Мальдивы продолжали получать льготы в рамках участия в SAFTA). В дополнение ко всему Индия может отменить или уменьшить преференции либо прочие меры, если импорт представляет собой существенную угрозу для национального производства, что соответствует мерам, описанным в ст. ХІХ ГАТТ, но только в отношении НРС.

Японская ОСП была введена 1 августа 1971 г. Режим беспошлинной и неквотируемой торговли практически всеми товарами, которые произведены в 48 НРС, входящих в список ООН, был объявлен в декабре 2005 г. в рамках японской Программы развития торговли ${ }^{2}$. С тех пор программа была усовершенствована. Ее современная версия датируется апрелем 2007 г. и будет иметь силу до 2021 г. $^{3}$ Это вполне соотносится с японской практикой долгосрочной стабильности в программах преференциального доступа.

Япония закрепила за собой право в одностороннем порядке устанавливать, отменять или ограничивать бенефициаров или товары, к которым отно-

1 Duty Free Tariff Preference (DFTPI-LDC) Scheme announced by India for Least Developed Countries (LDCs), updated 01-01-2012, available at: http://commerce.gov.in/ trade/international tpp DFTP.pdf

2 Japan's New Development Initiative for Trade. Viewed at http://www.mof.go.jp/ english/tariff/ wto/wto.htm

3 Детальная информация доступна на сайmе Japanese Ministry of Foreign Affairs: http://www.mofa.go.jp/ policy/economy/gsp/index.html 
сятся преференции в рамках программы тарифных преференций. Страна исключается из списка бенефициаров, когда она классифицируется Всемирным банком как страна с высоким уровнем доходов в течение трех предшествующих лет. (Это более узкое определение, чем то, которое использует $\mathrm{OOH}$, принимая во внимание множество прочих показателей развития.)

Япония проводит ежегодное исследование, по результатам которого наиболее конкурентоспособные товары из развивающейся страны-бенефициара исключаются из программы тарифных преференций, если: а) импорт насчитывает более $50 \%$ общего объема японского импорта этого продукта за три года или б) объем импорта за тот же период превышает 1,5 трлн йен. Однако это не относится к НРС.

ОСП Кореи была впервые объявлена в президентском указе о преференциальных тарифах для НРС в январе 2000 г. ВТО была уведомлена в апреле 2000 г. (документ WT/COMTD/N/12/ Rev.1). Программа охватывает 48 развивающихся стран, признанных ООН.

Изначально льготные тарифы относились только к 80 товарам, к 2011 г. программа расширилась и покрывала 95\% корейских тарифных позиций (4802 товара в шестизначных кодах ГС 2007)ํ․․

Указ об утверждении беспошлинного и неквотируемого режима не содержит пункта, подтверждающего, что список ООН является ключевым критерием для допуска. Однако корейская программа изучения торговли 2008 г., проведенная ВТО, отметила, что «министр стратегии и финансов может отменить или изменить в одностороннем порядке торговые льготы, если будет решено принять во внимание уровень доходов в стране, объемы импорта и международную конкурентоспособность продукции и страны в целом.

Условия отмены тарифных льгот в Корее похожи на стандартные процедуры в рамках ВТО. Например, в президентском указе сказано, что «случаи, когда резкое увеличение импорта продуктов, имеющих тарифные преференции, вредит или представляет угрозу национальным предприятиям, которые производят похожую продукцию или товары-субституты, то соответствующее министерство или заинтересованное лицо может обратиться в Министерство финансов, чтобы попросить об отмене преференции для данного товара» ${ }^{2}$.

1 WT/COMTD/N/12/Rev.1/Add. 120 March 2012. Тариф был обновлен на основе HS2012, действующей в Корее.

2 Presidential Decree on Preferential Tariff for Least-Developed Countries (Jan 10, 2000), Article 4. 1. This language is re-peated in Article 4.1 of the revised Presidential Decree No 23428, as notified to the WTO in WT/COMTD/N/12/Rev.1/Add. 1 of 20 March 2012. 
Программа США «Наименее развитые развивающиеся страны-бенефициары» (НРСБ) - подкатегория их системы тарифных преференций. Льготы также предоставляются странам в рамках Акта об обеспечении роста и возможностей в Африке (AGOA) и Гаити - единственной развивающейся стране в западном полушарии - в рамках Инициативы относительно стран Карибского бассейна. На сегодняшний день программа НРСБ охватывает 44 развивающихся страны, среди которых самой поздней из присоединившихся стран стал Южный Судан. Исключенными странами являются Экваториальная Гвинея, Эфиопия, Лаосская Народно-Демократическая Республика, Мьянма, Сенегал и (Северный) Судан. Эти исключения были обоснованы политически ${ }^{1}$.

Программа обеспечивает беспошлинный доступ, а не преференциальные скидки всем развивающимся странам 2 . Основное отличие стран с низшим уровнем экономического развития и прочих развивающихся стран заключается в охвате тарифных позиций: развивающиеся страны получают выгоды приблизительно от 1430 тарифных линий, в то время как остальные участники программы тарифных преференций - по 3451 товарам. Однако существуют ограничения по объему беспошлинного импорта. Любой импорт свыше этого объема подвергается обложению пошлинами по ставке РНБ.

Список товаров, участвующих в программе тарифных преференций всех бенефициаров, включает в основном не имеющие стратегического значения, подлежащие обложению пошлинами товары и полуфабрикаты, такие, как сельскохозяйственные и рыбные продукты, промышленное сырье, которые в общем случае подлежат таможенному обложению. Определенные ключевые импортные позиции, исключенные из системы тарифных преференций, включают нешелковые текстильные товары, часы, обувь, сумки, товары для дома и отдельные виды одежды. Продукты, на которые распространяется беспошлинный режим, только в случае, если они импортируются из развивающихся стран, включают в себя бензин, определенные химикаты и пластмассы, продукты животного и растительного происхождения, еду, алкоголь и табачные изделия. В то время как выгоды ОСП для текстильных товаров и одежды довольно ограниченны, некоторые изделия народных промыслов получают преференции. В список стран, имеющих право на преференции, входят азиатские НРС (Афганистан, Камбоджа, Непал и Восточный Тимор). Подобные преференции позволяют расширять беспошлинные режимы для экспортных товаров, произведенных женщинами и бедняками - жителями страны-бенефициара.

$1 \quad$ Presidential Decree on Preferential Tariff for Least-Developed Countries (Jan 10, 2000), Article 4. 1. This language is re-peated in Article 4.1 of the revised Presidential Decree No 23428, as notified to the WTO in WT/COMTD/N/12/Rev.1/Add. 1 of 20 March 2012. 
Усовершенствования в сфере охвата продукции и стран проводятся ежегодно Комитетом программы тарифных преференций. Заинтересованные стороны, включая страны-бенефициары и представителей ООН, могут требовать усовершенствований, которые, пройдя через Комитет, вступают в силу после указа президента.

Через какое-то время США расширили список критериев, которым должны соответствовать страны-бенефициары. Основные критерии относятся к защите интеллектуальной собственности, уважению прав трудящихся и разрешению инвестиционных споров. Несмотря на то, что Соглашение по торговым аспектам прав интеллектуальной собственности (ТРИПС) непосредственно не обозначено в Руководстве ОСП США, составленном Конвенцией МОТ, США отменили определенные тарифные льготы для отдельных стран по причине несоответствия требованиям ТРИПС $\mathbf{1}$. Закон Соединенных Штатов также позволяет торговому представителю предлагать дополнительные льготы странам, сотрудничающим с США. Эти обстоятельства принимаются во внимание при рассмотрении отказа в рамках предоставления льгот по соображениям, связанным с высокой конкурентоспособностью.

\section{3. Охват тарифных позиций и торговли. Тарифные режимы и использование преференций}

Зона действия беспошлинного режима. Несмотря на то, что большая доля импорта из признанных ООН НРС идет в Канаду, Китай, ЕС и Японию, только 68,5\% импорта в США поступает на таких же условиях. Соответствующие показатели для Индии и Кореи составляют 5,7 и 39,1\% (табл. 3$)^{2}$. Корея планирует расширить покрытие тарифных линий для НРС до 95\% к 2012 г. $^{3}$ Согласно данным ВТО, доля тарифных позиций, получивших выгоды от беспошлинного режима в 2009 г., в Канаде составила 98,8\%, в ЕС 99,3, в Корее - 72,1, в Японии - 98 и в США - 84,2\%.

1 U. S. Generalised System of Preferences (GSP) Guidebook, available at: http://www. ustr. gov/ webfm send/2880

2 Имеются различия в применении преференций для НРС, например, промышленно развитые страны и Корея распространяют ее не на все 49 НРС, которые определены ООН (причины рассмотрены далее в п. 6). Данные по Японии взяты из табл. 1.

3 Korean Ministry of Strategy and Finance Press Release of 17 November 2010. Дополнительные позиции включают нечувствительные сельскохозяйственные товары и морепродукты - иветы, специи, жиры и масла, текстильные товары, инструменты и др. 


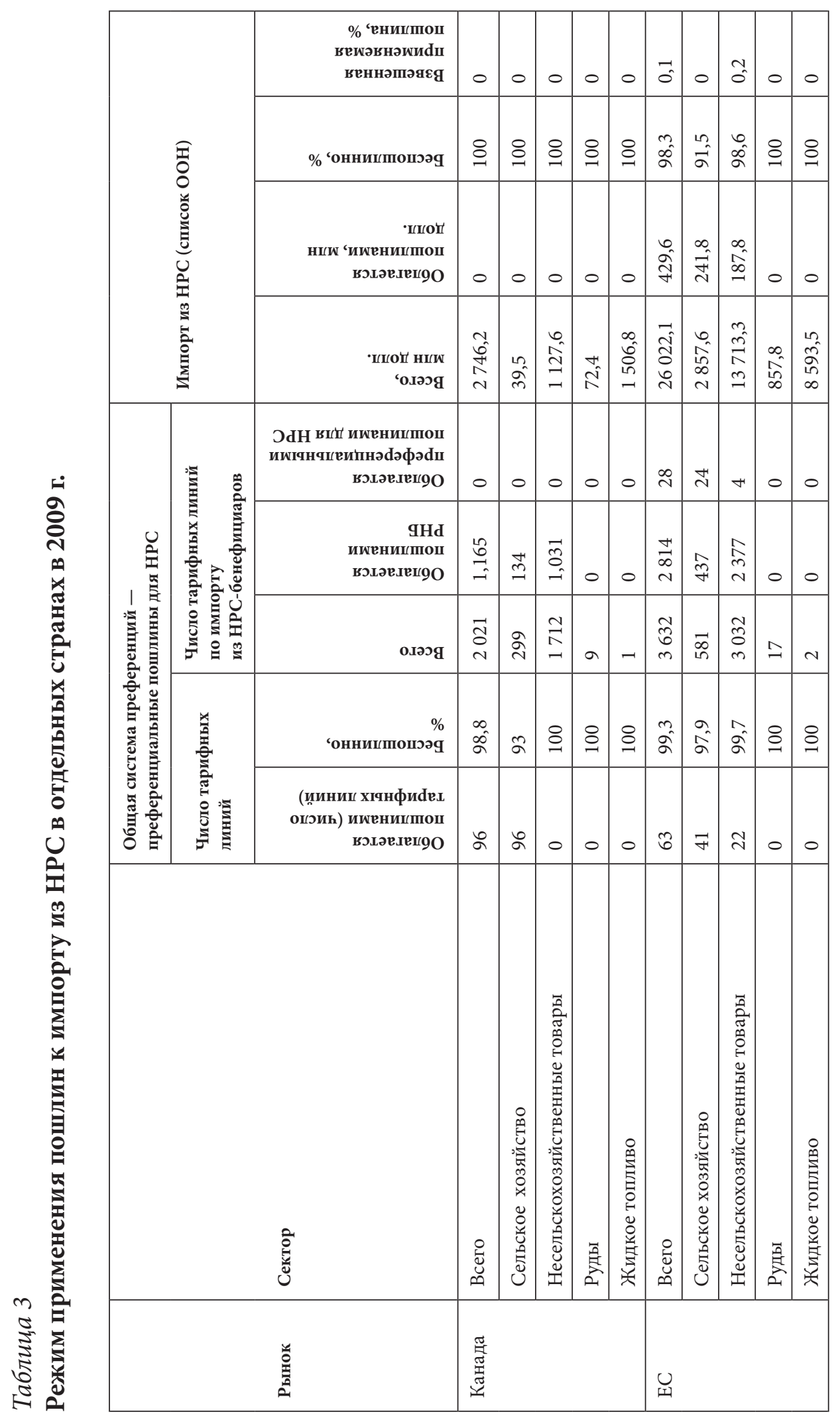




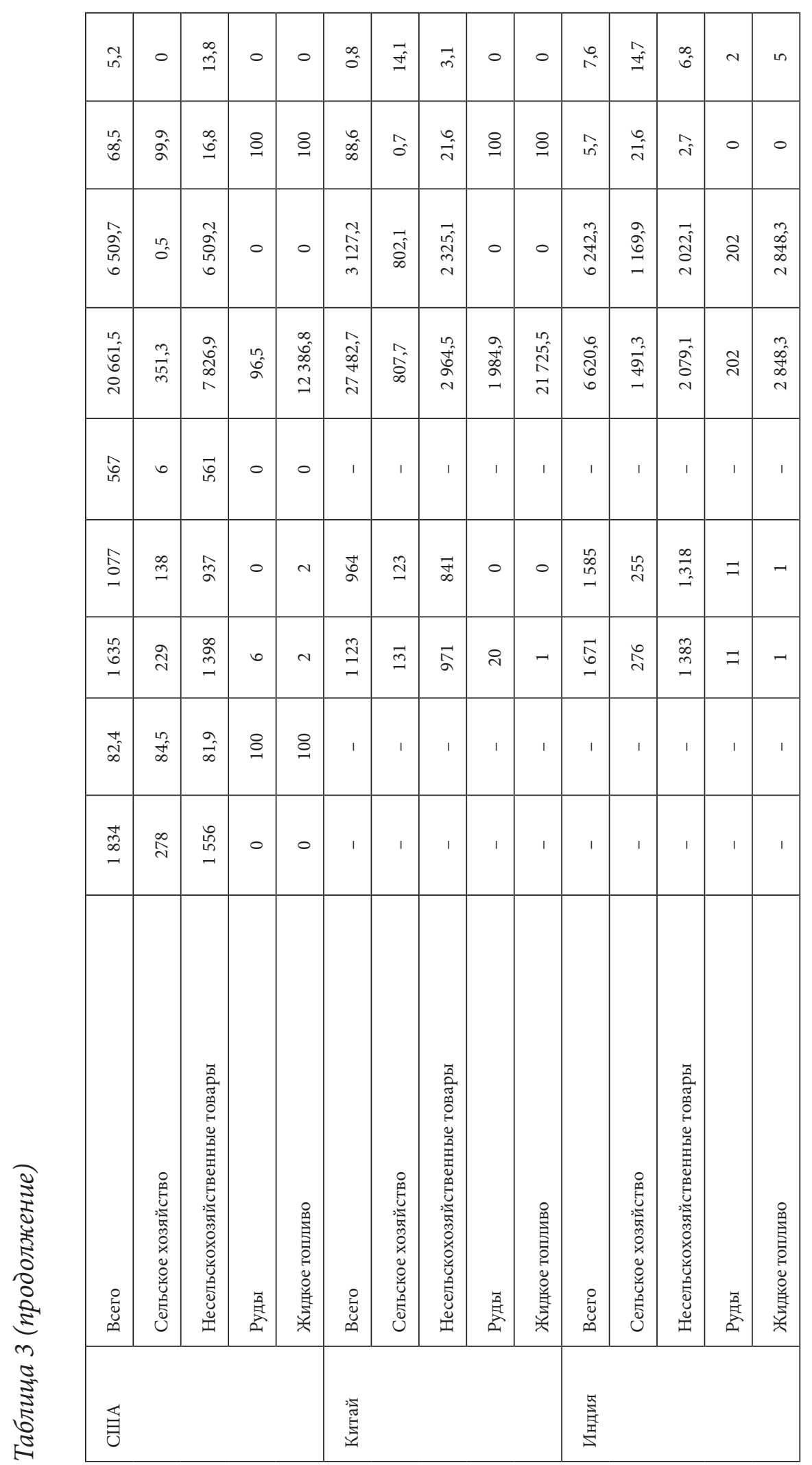




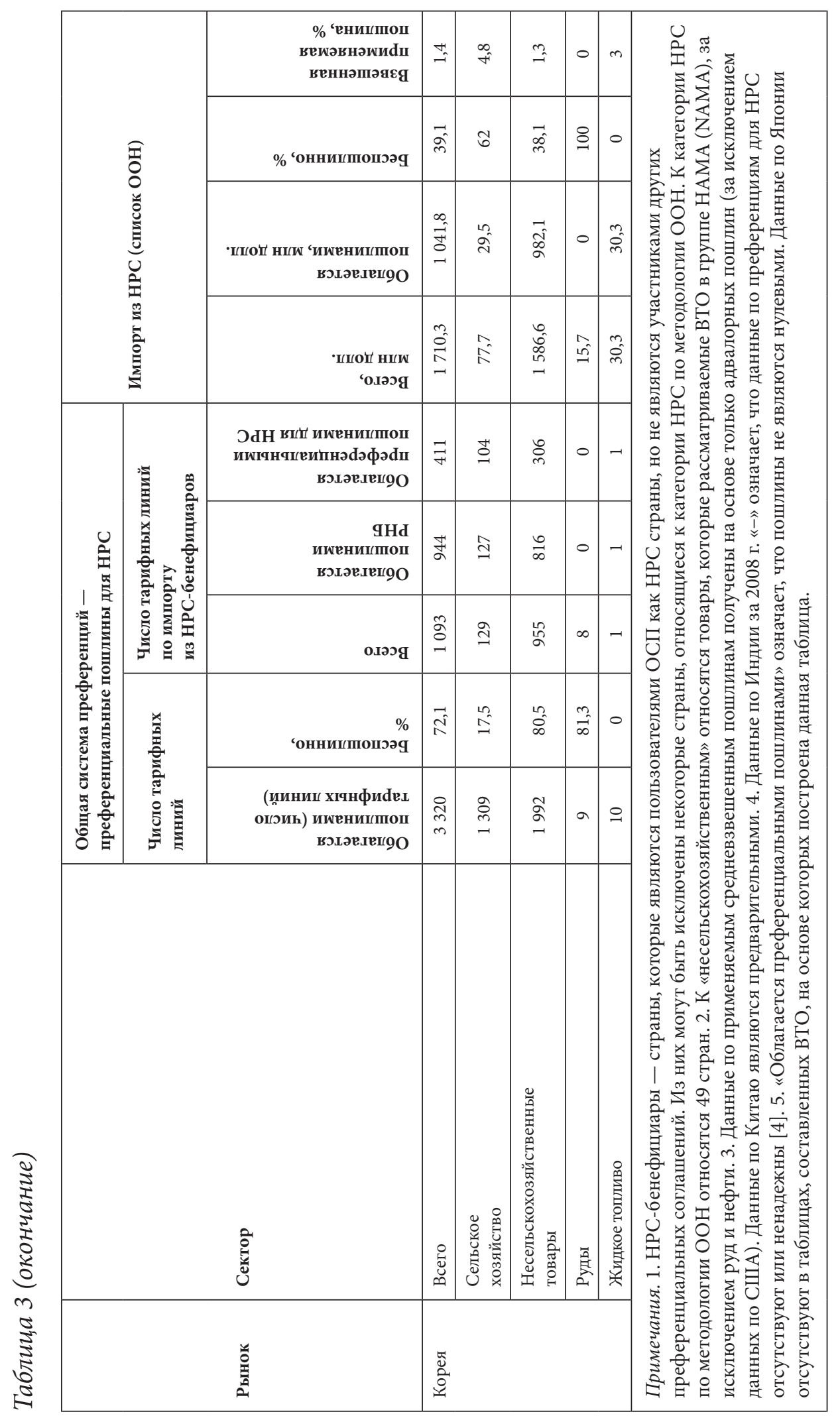




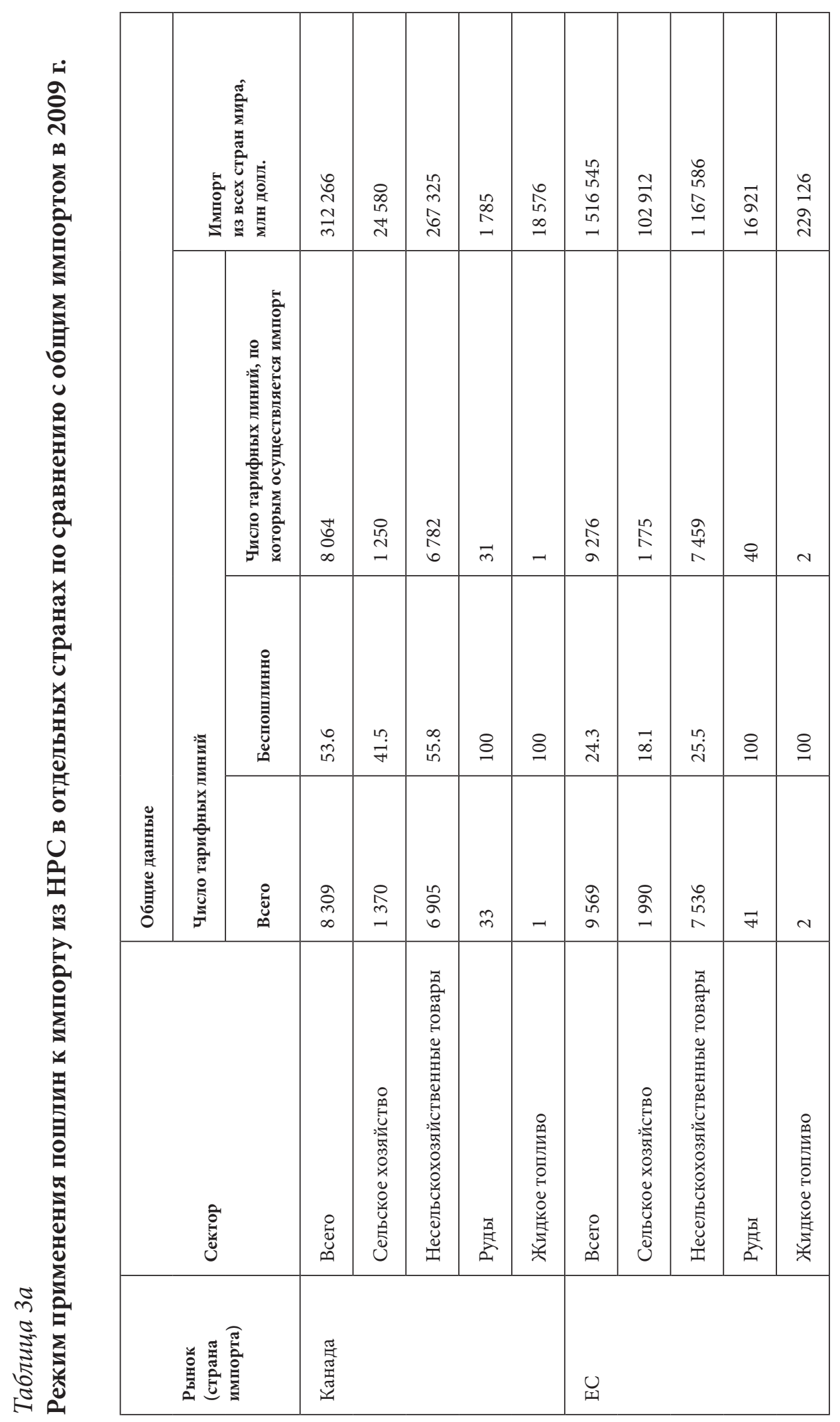




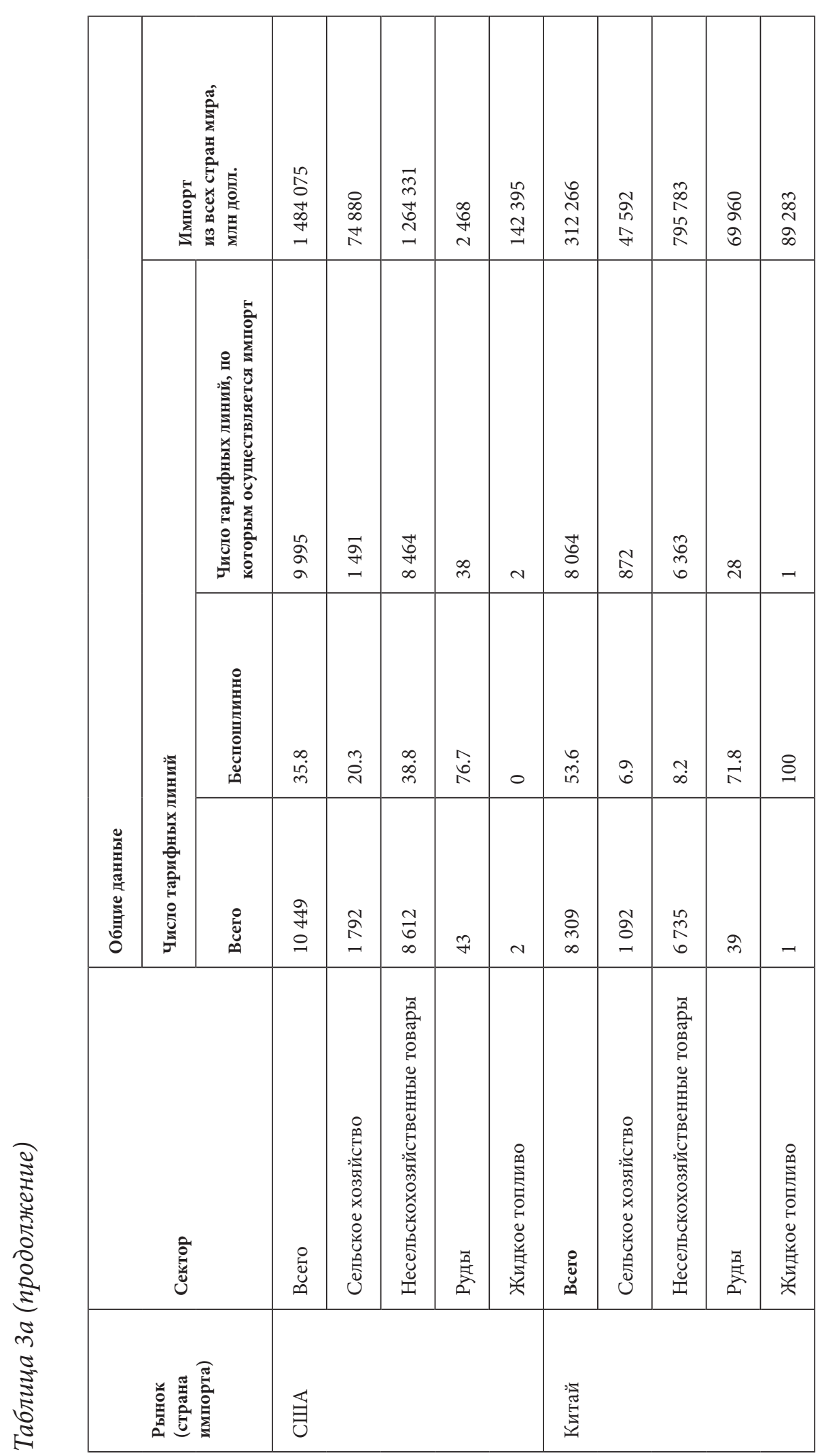




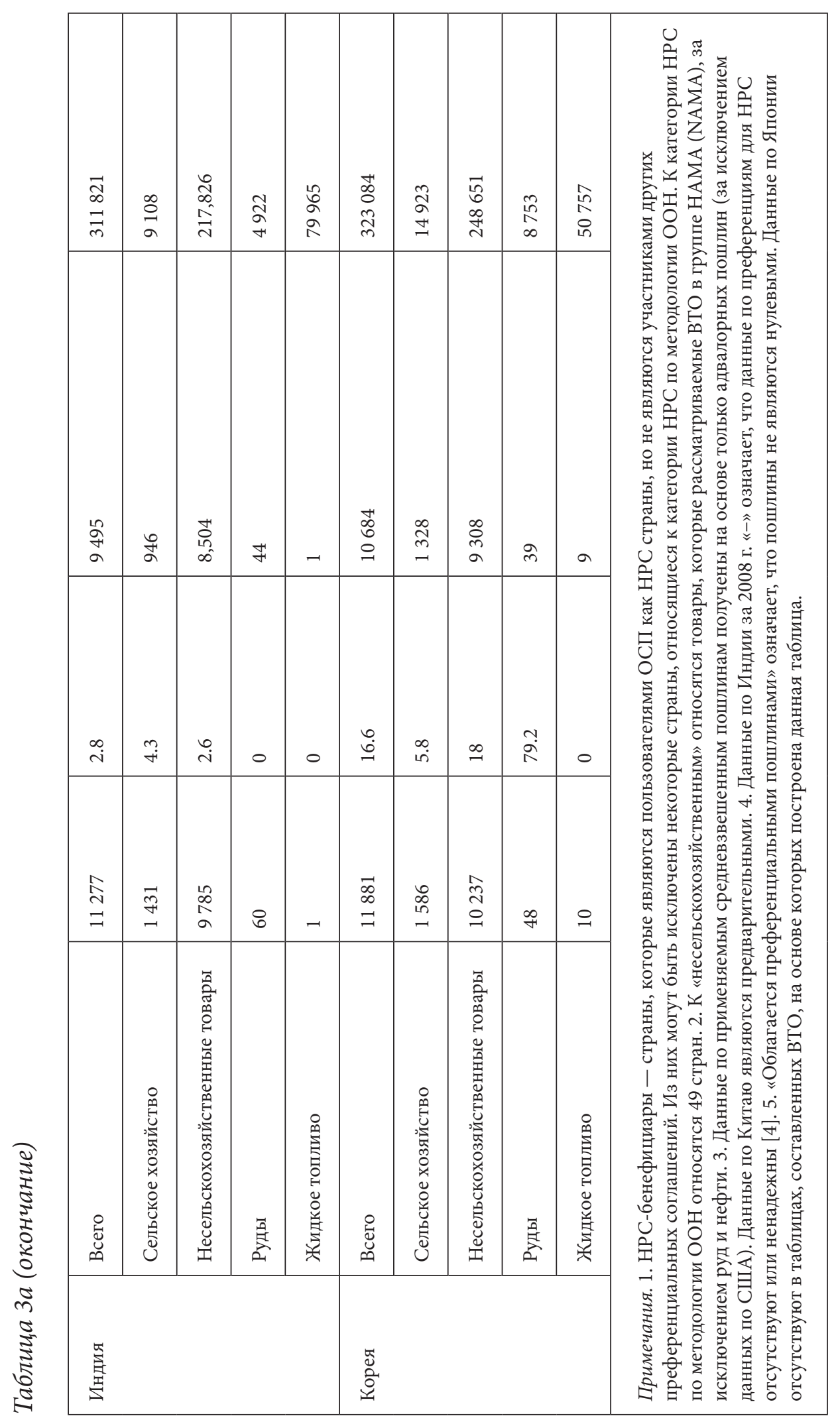


В 2011 г. Китай уведомил ВТО, что его беспошлинный и неквотируемый режим расширился и покрывает 60\% тарифных линий, в то время как Индия сообщила, что выгоды для НРС составили 85\% всех тарифных линий. Планируется, что в Индии режим импорта станет беспошлинным через пять лет за счет равномерных ежегодных сокращений пошлин. В дополнение, Индия взяла на себя обязательства сократить преференции на 468 товаров (около 9\% всех тарифных линий) из расчета преференциальных скидок (основанных, скорее, на постоянных, чем на связанных ставках таможенного тарифа РНБ) за пять лет. Пошлины не будут сокращены для 326 тарифных линий, вошедших в список исключенных товаров. Со временем страны, чьи рынки рассматриваются в этой статье, сделали свои беспошлинные схемы более привлекательными для НРС. Таможенные ставки были уменьшены, а охват таможенных позиций и импорта был увеличен (табл. 4)로.

В 2010 г. канадские и японские средние таможенные ставки для общей торговли, не связанной с нефтью, составляли $0,3 \%$. Средняя таможенная ставка в ЕС была 0,9\%, а в США - 3,3 \%. Для Китая, Индии и Кореи соответствующие ставки составляют $6,0,12,6$ и $10,2 \%$.

С 2000 г. доля беспошлинного импорта товаров, не связанных с нефтью и оружием, как доля всеобщего импорта значительно повысилась на всех рынках, рассмотренных в данной статье, за исключением ЕС, где был отмечен 20\%-ный спад. Однако к статистике надо относиться осторожно, так как количество исключенных товаров уменьшилось в период с 2000 по 2010 г. Это объясняется тем, что статистика основывается на данных зарегистрированной торговли, а процентные доли могут подвергаться влиянию изменений общих условий торговли, продукции и торговых партнеров.

Отраслевой охват. Для Канады, ЕС и Кореи количество беспошлинных тарифных линий для несельскохозяйственных товаров больше, чем для сельскохозяйственных, а в США немного больше тарифных линий для сельскохозяйственных товаров (см. табл. 3). (Наименьший охват тарифных позиций для промышленных товаров отражает большое количество исключенных товаров в текстильной отрасли.) Развитые страны предоставляют 100\%-ный беспошлинный ввоз руды и бензина из НРС. Корея охватывает 81,3\% импорта руды, но полностью исключает ввоз бензина.

1 Изменения средних пошлин, применяемых к товарам НРС (по списку ООН), а также их соотношение с общим числом тарифных линий и беспошлинных линий $\kappa$ общему числу линий на 2000 и 2010 гг. показаны в табл. 3. Основное отличие от табл. 2 заключается в том, что она подготовлена на основе данных общедоступной системы WITS, являющейся совместным продуктом ІТС, Центр ЮНКТАД/ ВТО по международной торговле, ЮНКТАД, Всемирного банка и ВТО. При этом данные представлены только по позициям, по которым осуществлялась торговля, что может сказаться на результатах. 


\section{Таблица 4}

Ставки пошлин, отношения числа беспошлинных свободных тарифных линий к их общему числу и импорт из НРС в 2000 и 2010 гг., \%

\begin{tabular}{|c|c|c|c|c|c|c|}
\hline \multirow[t]{2}{*}{ Импортер/товар } & \multicolumn{2}{|c|}{$\begin{array}{l}\text { Средняя ставка } \\
\text { тарифа }\end{array}$} & \multicolumn{2}{|c|}{$\begin{array}{l}\text { Отношение } \\
\text { беспошлинного } \\
\text { импорта к общему } \\
\text { объему торговли }\end{array}$} & \multicolumn{2}{|c|}{$\begin{array}{l}\text { Отношение числа } \\
\text { тарифных линий } \\
\text { с нулевой ставкой } \\
\text { к общему числу } \\
\text { тарифных линий }\end{array}$} \\
\hline & 2000 г. & 2010 г. & 2000 г. & 2010 г. & 2000 г. & 2010 r. \\
\hline \multicolumn{7}{|l|}{ Канада } \\
\hline $\begin{array}{l}\text { Сельскохозяйственные } \\
\text { товары } \\
(\text { SITC } 0+1+2-27-28+4)\end{array}$ & 0,5 & 0,2 & 75,5 & 89,6 & 97,4 & 99,8 \\
\hline $\begin{array}{l}\text { Сельскохозяйственное } \\
\text { сырье } \\
\text { (SITC 2-22-27-28) }\end{array}$ & 0,3 & 0,1 & 82,4 & 97,2 & 99,8 & 100,0 \\
\hline $\begin{array}{l}\text { Продовольствие } \\
(\text { SITC } 0+1+22+4)\end{array}$ & 0,6 & 0,2 & 74,0 & 88,9 & 96,5 & 99,7 \\
\hline Топливо (SITC 3) & 0,0 & 0,0 & 0100,0 & 100,0 & 100,0 & 100,0 \\
\hline $\begin{array}{l}\text { Руды и металлы } \\
\text { (SITC 27+28+68) }\end{array}$ & 0,0 & 0,0 & 100 & 100,0 & 100,0 & 100,0 \\
\hline $\begin{array}{l}\text { Химическая } \\
\text { продукция (SITC 5) }\end{array}$ & 0,1 & 0,1 & 94,3 & 96,7 & 2,7 & 100,0 \\
\hline Готовые изделия & 7,4 & 0,3 & 74,8 & 97,0 & 13,4 & 100,0 \\
\hline $\begin{array}{l}\text { Прочая обработанная } \\
\text { продукция } \\
(\text { SITC 6+8-68) }\end{array}$ & 9,2 & 0,4 & 63,3 & 96,5 & 6,0 & 100,0 \\
\hline $\begin{array}{l}\text { Текстиль } \\
\text { (SITC Rev.1 26+65+84) }\end{array}$ & 15,6 & 0,7 & 32,1 & 96,2 & 7,0 & 100,0 \\
\hline $\begin{array}{l}\text { Машины, } \\
\text { оборудование и } \\
\text { транспортные средства } \\
\text { (SITC 7) }\end{array}$ & 0,0 & 0,0 & 100,0 & 98,5 & 100,0 & 99,6 \\
\hline $\begin{array}{l}\text { Различные товары } \\
\text { (SITC 9) }\end{array}$ & 0,0 & 0,0 & 100,0 & 100,0 & 100,0 & 100,0 \\
\hline $\begin{array}{l}\text { Все товары, за } \\
\text { исключением оружия } \\
\text { (95) }\end{array}$ & 7,2 & 0,4 & 67,5 & 95,0 & 34,0 & 100,0 \\
\hline $\begin{array}{l}\text { Всего торговля, за } \\
\text { исключением жидкого } \\
\text { топлива }\end{array}$ & 6,2 & 0,3 & 75,2 & 95,7 & 31,0 & 100,0 \\
\hline
\end{tabular}


Таблица 4 (продолжение)

\begin{tabular}{|c|c|c|c|c|c|c|}
\hline \multirow[t]{2}{*}{ Импортер/товар } & \multicolumn{2}{|c|}{$\begin{array}{l}\text { Средняя ставка } \\
\text { тарифа }\end{array}$} & \multicolumn{2}{|c|}{$\begin{array}{l}\text { Отношение } \\
\text { беспошлинного } \\
\text { импорта к общему } \\
\text { объему торговли }\end{array}$} & \multicolumn{2}{|c|}{$\begin{array}{l}\text { Отношение числа } \\
\text { тарифных линий } \\
\text { с нулевой ставкой } \\
\text { к общему числу } \\
\text { тарифных линий }\end{array}$} \\
\hline & 2000 r. & 2010 г. & 2000 r. & 2010 г. & 2000 г. & $2010 \mathrm{r}$ \\
\hline \multicolumn{7}{|l|}{ Китай } \\
\hline $\begin{array}{l}\text { Сельскохозяйственные } \\
\text { товары (SITC } 0+1+2- \\
27-28+4)\end{array}$ & 19,0 & 5,3 & 7,6 & 62,2 & 0,0 & 75,5 \\
\hline $\begin{array}{l}\text { Сельскохозяйственное } \\
\text { сырье } \\
\text { (SITC 2-22-27-28) }\end{array}$ & 13,7 & 3,2 & 1,9 & 63,4 & 0,0 & 72,1 \\
\hline $\begin{array}{l}\text { Продовольствие } \\
(\text { SITC } 0+1+22+4)\end{array}$ & 23,8 & 6,9 & 14,1 & 60,0 & 0,0 & 82,1 \\
\hline Топливо (SITC 3) & 3,0 & 2,0 & 0,0 & 28,7 & 0,0 & 99,7 \\
\hline $\begin{array}{l}\text { Химическая } \\
\text { продукция (SITC 5) }\end{array}$ & 16,6 & 6,3 & 0,0 & 43,7 & 0,0 & 56,8 \\
\hline Готовые изделия & 18,5 & 6,0 & 1,6 & 46,5 & 0,0 & 62,5 \\
\hline $\begin{array}{l}\text { Руды и металлы } \\
(\text { SITC 27+28+68) }\end{array}$ & 2,0 & 0,0 & 40,8 & 100,0 & 24,6 & 100,0 \\
\hline $\begin{array}{l}\text { Прочая обработанная } \\
\text { продукция } \\
\text { (SITC 6+8-68) }\end{array}$ & 19,3 & 0,6 & 2,4 & 82,6 & 0,0 & 93,2 \\
\hline $\begin{array}{l}\text { Текстильные товары } \\
\text { (SITC Rev.1 26+65+84) }\end{array}$ & 25,9 & 6,6 & 0,0 & 45,5 & 0,0 & 63,8 \\
\hline $\begin{array}{l}\text { Машины, } \\
\text { оборудование и } \\
\text { транспортные средства } \\
\text { (SITC 7) }\end{array}$ & 15,1 & 3,3 & 0,0 & 50,0 & 0,0 & 49,8 \\
\hline $\begin{array}{l}\text { Все товары, за } \\
\text { исключением оружия } \\
(95)\end{array}$ & 19,4 & 6,6 & 7,8 & 41,6 & 0,6 & 23,6 \\
\hline $\begin{array}{l}\text { Всего торговля, за } \\
\text { исключением жидкого } \\
\text { топлива }\end{array}$ & 17,7 & 6,0 & 6,3 & 47,7 & 4,8 & 96,9 \\
\hline \multicolumn{7}{|l|}{ EC } \\
\hline $\begin{array}{l}\text { Сельскохозяйственные } \\
\text { товары } \\
(\text { SITC } 0+1+227-28+4)\end{array}$ & 0,0 & 0,2 & 83,7 & 85,1 & 98,8 & 95,4 \\
\hline $\begin{array}{l}\text { Сельскохозяйственное } \\
\text { сырье } \\
\text { (SITC 2-22-27-28) }\end{array}$ & 0,0 & 0,3 & 100,0 & 85,7 & 100,0 & 91,4 \\
\hline $\begin{array}{l}\text { Продовольствие } \\
(\text { SITC } 0+1+22+4)\end{array}$ & 0,1 & 0,2 & 80,9 & 85,0 & 98,4 & 96,1 \\
\hline
\end{tabular}


Таблища 4 (продолжение)

\begin{tabular}{|c|c|c|c|c|c|c|}
\hline \multirow[t]{2}{*}{ Импортер/товар } & \multicolumn{2}{|c|}{$\begin{array}{l}\text { Средняя ставка } \\
\text { тарифа }\end{array}$} & \multicolumn{2}{|c|}{$\begin{array}{l}\text { Отношение } \\
\text { беспошлинного } \\
\text { импорта к общему } \\
\text { объему торговли }\end{array}$} & \multicolumn{2}{|c|}{$\begin{array}{l}\text { Отношение числа } \\
\text { тарифных линий } \\
\text { с нулевой ставкой } \\
\text { к общему числу } \\
\text { тарифных линий }\end{array}$} \\
\hline & 2000 г. & 2010 r. & 2000 г. & 2010 r. & 2000 г. & 2010 r \\
\hline Топливо (SITC 3) & 0,0 & 1,2 & 100,0 & 53,8 & 100,0 & 97,6 \\
\hline $\begin{array}{l}\text { Руды и металлы } \\
(\text { SITC 27+28+68) }\end{array}$ & 0,0 & 0,0 & 100,0 & 99,3 & 100,0 & 100,0 \\
\hline $\begin{array}{l}\text { Химическая } \\
\text { продукция (SITC 5) }\end{array}$ & 0,0 & 1,6 & 99,8 & 51,4 & 100,0 & 99,3 \\
\hline Готовые изделия & 0,0 & 1,1 & 100,0 & 64,9 & 100,0 & 94,6 \\
\hline $\begin{array}{l}\text { Прочая обработанная } \\
\text { продукция } \\
\text { (SITC 6+8-68) }\end{array}$ & 0,0 & 1,1 & 100,0 & 71,5 & 100,0 & 97,2 \\
\hline $\begin{array}{l}\text { Текстиль } \\
\text { (SITC Rev.1 26+65+84) }\end{array}$ & 0,0 & 0,7 & 100,0 & 92,5 & 100,0 & 98,0 \\
\hline $\begin{array}{l}\text { Машины, оборудова- } \\
\text { ние и транспортные } \\
\text { средства (SITC 7) }\end{array}$ & 0,0 & 1,1 & 100,0 & 57,4 & 100,0 & 55,7 \\
\hline $\begin{array}{l}\text { Различные товары } \\
\text { (SITC 9) }\end{array}$ & 0,0 & 0,0 & 100,0 & 100,0 & 100,0 & 100,0 \\
\hline $\begin{array}{l}\text { Все товары, за } \\
\text { исключением оружия } \\
(95)\end{array}$ & 0,0 & 0,9 & 92,6 & 75,3 & 99,7 & 97,4 \\
\hline $\begin{array}{l}\text { Всего торговля, за } \\
\text { исключением жидкого } \\
\text { топлива }\end{array}$ & 0,0 & 0,9 & 94,8 & 70,9 & 99,7 & 95,7 \\
\hline \multicolumn{7}{|l|}{ Индия за 1999 и 2009 гг. } \\
\hline $\begin{array}{l}\text { Сельскохозяйственные } \\
\text { товары } \\
(\text { SITC } 0+1+2-27-28+4)\end{array}$ & 24,9 & 23,9 & 12,6 & 25,5 & 33,9 & 90,7 \\
\hline $\begin{array}{l}\text { Сельскохозяйственное } \\
\text { сырье } \\
\text { (SITC 2-22-27-28) }\end{array}$ & 13,1 & 11,4 & 20,6 & 28,3 & 1,6 & 83,9 \\
\hline $\begin{array}{l}\text { Продовольствие } \\
(\text { SITC } 0+1+22+4)\end{array}$ & 34,4 & 30,7 & 6,3 & 23,4 & 59,6 & 91,4 \\
\hline Топливо (SITC 3) & 21,7 & 2,6 & 0,0 & 27,8 & 0,0 & 99,9 \\
\hline $\begin{array}{l}\text { Руды и металлы } \\
(\text { SITC 27+28+68) }\end{array}$ & 30,3 & 4,6 & 0,0 & 1,3 & 0,0 & 0,0 \\
\hline $\begin{array}{l}\text { Химическая } \\
\text { продукция (SITC 5) }\end{array}$ & 34,3 & 10,2 & 0,0 & 0,0 & 0,0 & 0,0 \\
\hline
\end{tabular}


Таблица 4 (продолжение)

\begin{tabular}{|c|c|c|c|c|c|c|}
\hline \multirow[t]{2}{*}{ Импортер/товар } & \multicolumn{2}{|c|}{$\begin{array}{l}\text { Средняя ставка } \\
\text { тарифа }\end{array}$} & \multicolumn{2}{|c|}{$\begin{array}{l}\text { Отношение } \\
\text { беспошлинного } \\
\text { импорта к общему } \\
\text { объему торговли }\end{array}$} & \multicolumn{2}{|c|}{$\begin{array}{l}\text { Отношение числа } \\
\text { тарифных линий } \\
\text { с нулевой ставкой } \\
\text { к общему числу } \\
\text { тарифных линий }\end{array}$} \\
\hline & 2000 г. & 2010 г. & 2000 г. & 2010 г. & 2000 г. & 2010 r. \\
\hline Готовые изделия & 34,6 & 9,5 & 0,2 & 4,5 & 0,0 & 1,2 \\
\hline $\begin{array}{l}\text { Прочая обработанная } \\
\text { продукция } \\
\text { (SITC 6+8-68) }\end{array}$ & 35,7 & 9,4 & 0,2 & 0,2 & 0,0 & 0,0 \\
\hline $\begin{array}{l}\text { Текстиль } \\
\text { (SITC Rev.1 26+65+84) }\end{array}$ & 35,2 & 9,3 & 0,0 & 21,9 & 0,0 & 88,6 \\
\hline $\begin{array}{l}\text { Машины, оборудова- } \\
\text { ние и транспортные } \\
\text { средства (SITC 7) }\end{array}$ & 28,5 & 9,5 & 0,0 & 17,6 & 0,0 & 30,9 \\
\hline $\begin{array}{l}\text { Различные товары } \\
\text { (SITC 9) }\end{array}$ & 40,0 & 10,0 & 0,0 & 0,0 & 0,0 & 0,0 \\
\hline $\begin{array}{l}\text { Все товары, за исклю- } \\
\text { чением оружия (95) }\end{array}$ & 31,8 & 13,1 & 4,5 & 7,5 & 19,5 & 59,0 \\
\hline $\begin{array}{l}\text { Всего торговля, за } \\
\text { исключением жидкого } \\
\text { топлива }\end{array}$ & 31,1 & 12,6 & 4,1 & 9,1 & 21,5 & 41,1 \\
\hline \multicolumn{7}{|c|}{ Япония (данные по торговле за 2000-2010 гг, } \\
\hline $\begin{array}{l}\text { Сельскохозяйственные } \\
\text { товары } \\
(\text { SITC } 0+1+2-27-28+4)\end{array}$ & 2,9 & 0,4 & 45,9 & 90,5 & 44,3 & 94,2 \\
\hline $\begin{array}{l}\text { Сельскохозяйственное } \\
\text { сырье } \\
\text { (SITC 2-22-27-28) }\end{array}$ & 0,3 & 0,1 & 93,4 & 98,7 & 98,8 & 99,4 \\
\hline $\begin{array}{l}\text { Продовольствие } \\
(\text { SITC } 0+1+22+4)\end{array}$ & 4,0 & 0,5 & 25,5 & 86,9 & 39,2 & 93,8 \\
\hline Топливо (SITC 3) & 2,1 & 0,0 & 19,0 & 100,0 & 0,0 & 100,0 \\
\hline $\begin{array}{l}\text { Руды и металлы } \\
\text { (SITC 27+28+68) }\end{array}$ & 0,0 & 0,0 & 100,0 & 100,0 & 100,0 & 100,0 \\
\hline $\begin{array}{l}\text { Химическая } \\
\text { продукция (SITC 5) }\end{array}$ & 0,0 & 0,2 & 94,3 & 84,6 & 97,6 & 95,3 \\
\hline Готовые изделия & 0,3 & 0,3 & 93,9 & 97,1 & 99,6 & 99,2 \\
\hline $\begin{array}{l}\text { Прочая обработанная } \\
\text { продукция } \\
\text { (SITC 6+8-68) }\end{array}$ & 0,0 & 0,0 & 100,0 & 98,6 & 100,0 & 100,0 \\
\hline $\begin{array}{l}\text { Текстиль } \\
\text { (SITC Rev.1 26+65+84) }\end{array}$ & 0,3 & 0,3 & 93,0 & 97,2 & 99,6 & 99,2 \\
\hline
\end{tabular}


Таблица 4 (продолжение)

\begin{tabular}{|c|c|c|c|c|c|c|}
\hline \multirow[t]{2}{*}{ Импортер/товар } & \multicolumn{2}{|c|}{$\begin{array}{l}\text { Средняя ставка } \\
\text { тарифа }\end{array}$} & \multicolumn{2}{|c|}{$\begin{array}{l}\text { Отношение } \\
\text { беспошлинного } \\
\text { импорта к общему } \\
\text { объему торговли }\end{array}$} & \multicolumn{2}{|c|}{$\begin{array}{l}\text { Отношение числа } \\
\text { тарифных линий } \\
\text { с нулевой ставкой } \\
\text { к общему числу } \\
\text { тарифных линий }\end{array}$} \\
\hline & 2000 r. & 2010 r. & 2000 r. & 2010 r. & 2000 г. & 2010 r. \\
\hline $\begin{array}{l}\text { Машины, оборудова- } \\
\text { ние и транспортные } \\
\text { средства (SITC 7) }\end{array}$ & 0,2 & 0,1 & 94,7 & 98,8 & 99,9 & 100,0 \\
\hline $\begin{array}{l}\text { Различные товары } \\
\text { (SITC 9) }\end{array}$ & 0,0 & 0,0 & 100,0 & 100,0 & 100,0 & 100,0 \\
\hline $\begin{array}{l}\text { Все товары, за исклю- } \\
\text { чением оружия (95) }\end{array}$ & 1,2 & 0,3 & 68,1 & 94,4 & 44,7 & 98,9 \\
\hline $\begin{array}{l}\text { Всего торговля, за } \\
\text { исключением жидкого } \\
\text { топлива }\end{array}$ & 1,0 & 0,3 & 73,4 & 94,7 & 64,2 & 97,1 \\
\hline
\end{tabular}

Корея (данные по торговле за 1999 г., тарифам за 2010 г. и торговле за 2009 г.)

\begin{tabular}{|c|c|c|c|c|c|c|}
\hline $\begin{array}{l}\text { Сельскохозяйственные } \\
\text { товары } \\
(\text { SITC } 0+1+2-27-28+4)\end{array}$ & 10,0 & 43,6 & 0,4 & 24,2 & 0,0 & 57,3 \\
\hline $\begin{array}{l}\text { Сельскохозяйственное } \\
\text { сырье } \\
\text { (SITC 2-22-27-28) }\end{array}$ & 3,9 & 4,1 & 0,0 & 47,6 & 0,0 & 94,0 \\
\hline $\begin{array}{l}\text { Продовольствие } \\
(\text { SITC } 0+1+22+4)\end{array}$ & 13,7 & 57,5 & 1,0 & 12,5 & 0,0 & 46,9 \\
\hline Топливо (SITC 3) & 5,1 & 3,7 & 0,0 & 1,5 & 0,0 & 76,6 \\
\hline $\begin{array}{l}\text { Руды и металлы } \\
\text { (SITC 27+28+68) }\end{array}$ & 2,6 & 0,0 & 0,0 & 100,0 & 0,0 & 100,0 \\
\hline $\begin{array}{l}\text { Химическая } \\
\text { продукция (SITC 5) }\end{array}$ & 7,6 & 0,8 & 0,0 & 96,8 & 0,0 & 98,8 \\
\hline Готовые изделия & 8,3 & 1,1 & 2,0 & 90,0 & 50,5 & 61,5 \\
\hline $\begin{array}{l}\text { Прочая обработанная } \\
\text { продукция } \\
(\text { SITC 6+8-68) }\end{array}$ & 9,1 & 0,1 & 2,2 & 94,0 & 0,0 & 100,0 \\
\hline $\begin{array}{l}\text { Текстиль } \\
\text { (SITC Rev.1 26+65+84) }\end{array}$ & 10,4 & 1,2 & 0,0 & 86,4 & 0,0 & 58,1 \\
\hline $\begin{array}{l}\text { Машины, оборудова- } \\
\text { ние и транспортные } \\
\text { средства (SITC 7) }\end{array}$ & 6,0 & 0,8 & 2,1 & 91,5 & 82,1 & 98,5 \\
\hline $\begin{array}{l}\text { Различные товары } \\
\text { (SITC 9) }\end{array}$ & 9,1 & 1,6 & 1,4 & 80,4 & 0,0 & 59,5 \\
\hline $\begin{array}{l}\text { Все товары, за исклю- } \\
\text { чением оружия (95) }\end{array}$ & 8,4 & 10,2 & 1,4 & 65,4 & 22,4 & 79,5 \\
\hline
\end{tabular}


Таблица 4 (окончание)

\begin{tabular}{|c|c|c|c|c|c|c|}
\hline \multirow[t]{2}{*}{ Импортер/товар } & \multicolumn{2}{|c|}{$\begin{array}{l}\text { Средняя ставка } \\
\text { тарифа }\end{array}$} & \multicolumn{2}{|c|}{$\begin{array}{l}\text { Отношение } \\
\text { беспошлинного } \\
\text { импорта к общему } \\
\text { объему торговли }\end{array}$} & \multicolumn{2}{|c|}{$\begin{array}{l}\text { Отношение числа } \\
\text { тарифных линий } \\
\text { с нулевой ставкой } \\
\text { к общему числу } \\
\text { тарифных линий }\end{array}$} \\
\hline & 2000 г. & 2010 г. & 2000 г. & 2010 г. & 2000 г. & 2010 г. \\
\hline \multicolumn{7}{|c|}{ США (данные по тарифам и торговле за 2000 г., тарифам 2010 и торговле 2009 гг.) } \\
\hline $\begin{array}{l}\text { Сельскохозяйственные } \\
\text { товары } \\
\text { (SITC } 0+1+2-27-28+4 \text { ) }\end{array}$ & 1,1 & 1,1 & 87,5 & 88,6 & 86,4 & 88,0 \\
\hline $\begin{array}{l}\text { Сельскохозяйственное } \\
\text { сырье } \\
\text { (SITC 2-22-27-28) }\end{array}$ & 0,3 & 0,0 & 90,7 & 95,6 & 99,4 & 98,2 \\
\hline $\begin{array}{l}\text { Продовольствие } \\
\text { (SITC } 0+1+22+4)\end{array}$ & 1,4 & 1,4 & 86,8 & 87,5 & 84,1 & 85,0 \\
\hline Топливо (SITC 3) & 0,0 & 0,0 & 100,0 & 97,9 & 100,0 & 100,0 \\
\hline $\begin{array}{l}\text { Руды и металлы } \\
\text { (SITC 27+28+68) }\end{array}$ & 0,5 & 0,1 & 94,9 & 98,9 & 99,7 & 83,4 \\
\hline $\begin{array}{l}\text { Химическая } \\
\text { продукция (SITC 5) }\end{array}$ & 0,0 & 0,0 & 98,5 & 100,0 & 99,8 & 100,0 \\
\hline Готовые изделия & 6,6 & 3,7 & 49,7 & 67,9 & 4,3 & 11,5 \\
\hline $\begin{array}{l}\text { Прочая обработанная } \\
\text { продукция } \\
\text { (SITC 6+8-68) }\end{array}$ & 7,7 & 4,5 & 38,2 & 60,0 & 3,5 & 10,3 \\
\hline $\begin{array}{l}\text { Текстиль } \\
\text { (SITC Rev.1 26+65+84) }\end{array}$ & 11,6 & 6,9 & 10,5 & 38,5 & 0,8 & 8,1 \\
\hline $\begin{array}{l}\text { Машины, оборудова- } \\
\text { ние и транспортные } \\
\text { средства (SITC 7) }\end{array}$ & 0,2 & 0,1 & 91,9 & 98,7 & 90,0 & 83,6 \\
\hline $\begin{array}{l}\text { Различные товары } \\
\text { (SITC 9) }\end{array}$ & 0,0 & 0,1 & 100,0 & 97,1 & 100,0 & 99,9 \\
\hline $\begin{array}{l}\text { Все товары, за исклю- } \\
\text { чением оружия (95) }\end{array}$ & 6,4 & 3,7 & 48,2 & 66,8 & 52,8 & 71,6 \\
\hline $\begin{array}{l}\text { Сельскохозяйственные } \\
\text { товары } \\
\text { (SITC } 0+1+2-27-28+4)\end{array}$ & 5,7 & 3,3 & 55,0 & 71,7 & 14,5 & 18,8 \\
\hline
\end{tabular}

Источник: WITS 
Более подробная информация об основных секторах (на базе тарифных линий там, где торговля зарегистрирована) показывает меньший охват беспошлинным режимом сельскохозяйственных продуктов на всех рынках, за исключением Индии. Это отражает тот факт, что индийская система тарифных преференций охватывает достаточно ограниченное количество промышленных товаров (табл. 4). В Японии охват сельскохозяйственных и пищевых продуктов за период с 2000 по 2010 г. удвоился более чем в два раза (около 95\%), в то время как охват сельскохозяйственных сырьевых материалов остался неизменным - 99\%.

Подробные данные подтверждают результаты более обобщенных данных, включая широкий охват канадской схемы и схемы ЕС, с самыми низкими таможенными ставками практически для всех экспортных товаров из НРС. В Японии немного более высокие ставки и меньший охват для таких товаров, как мех и некоторые продукты питания (злаковые, сахар, овощи, мясо и ракообразные). В США текстиль и одежда стоят особняком как отрасли с самыми высокими средними ставками и самым небольшим покрытием тарифных линий. Поскольку США предпочитают устанавливать беспошлинный режим вместо снижения ставок, эти данные отражают комбинацию товаров с нулевыми преференциальными ставками и товаров, исключенных из схемы преференций.

Китай предлагает высокие объемы торговли, низкие ставки и широкий охват тарифных линий и высокие доли импорта в таких областях, как масличные семена, руда, топливо, дерево, медь и прочие недрагоценные металлы. Это подтверждает тот факт, что изначально китайская схема была создана для того, чтобы стимулировать импорт, полезный для национальной экономики, как и в США.

Индия, чья система является относительно современной, обладает в целом небольшим беспошлинным охватом по сравнению с другими рынками, рассматриваемыми в настоящей статье. Эта страна предоставляет низкие ставки и широкое покрытие для топлива. Подробное изучение данных торговли показывает, что Индия ввозит большое количество кофе, чая и специй, несмотря на достаточно высокие средние тарифы, из чего можно сделать вывод, что хотя бы частично тарифы используются в фискальных целях подобно акцизам.

Как и остальные развивающиеся рынки, описанные здесь, Корея устанавливает самые низкие тарифы для большинства товаров в таких областях, как топливо, невыделанные кожа и шкуры, дерево, медь, что отражает ее необеспеченность природными ресурсами. В Корее также низкие ставки, большой объем импорта и широкий охват текстильных отраслей.

Использование преференций. Важно отметить, что импортируемые товары, номинально не подлежащие таможенному обложению, могут попасть 
на территорию страны, предоставляющей льготы по преференциальной ставке. Это может произойти по нескольким причинам, включая несоответствие правилам происхождения товаров. В результате доступные преференции не всегда используются в полной мере ${ }^{1}$.

Очень сложно оценить объем недоиспользования преференций, так как многие страны (за исключением США) не разделяют, что было импортировано из отдельных стран по преференциальным (реверсивным или нереверсивным) ставкам и ставкам РНБ. ВТО провела оценку использования на некоторых рынках, выбранных для данной статьи, различных льгот и установила, что коэффициент использования составляет от 82 до 89\% (табл. 5) ${ }^{2}$. Одно исследование японской системы, которое не охвачено ВТО и на основе которого составлена табл. 5, подтверждает, что коэффициент использования варьируется в зависимости от продукта, а наиболее чувствительными являются товары с низкими такими коэффициентами ${ }^{3}$. Исследование также показывает, что низкий коэффициент использования (47,1\% в 2005 г.) связан с всеобщей либерализацией торговли, что делает применение преференций менее интересным в связи с затратами на предоставление необходимых документов. Этим также объясняется низкий коэффициент использования импорта по преференциальным схемам в Канаде, ЕС и США (см. табл. 5).

Динамика. Спад в тарифных ставках для НРС в 2000-2010 гг. (см. табл. 4) является наиболее сильным за последние 20 лет (табл. 6). В 2010 г. импорт из НРС сталкивался со следующими тарифными ставками: от $0,0 \%$ в ЕС до 5,5\% в Китае. Однако ставки, с которыми сталкивается экспорт из НРС, были значительно сокращены на развитых рынках с 1990 по 2000 г. В ранние 1990-е годы импорт из развивающихся стран сталкивался со ставками РНБ, составляющими в Корее $13,1 \%$, в Китае - $42,3 \%$ и в Индии $-80,6 \%$. За 20 лет эти ставки были значительно сокращены в результате автономных программ по либерализации (корейские реформы прошли раньше), и ставки РНБ снизились до 11,8\% в Индии и до 9,6\% в Китае. Но даже значительное уменьшение ставок, с которыми сталкиваются НРС, принесло пользу рынкам указанных стран.

1 Секретариат ВТО отмечает, что преференции часто не используются из-за административных сложностей применения различных схем преферениий, зачастую предоставляемых на короткий период.

2 Этот индикатор не учитьвает беспошлинный ввоз в рамках РНБ. По мнению ВТО, оценить использование преференций очень трудно вследствие отсутствия статистики. Кроме того, экспорт из НРС может быть объектом применения различных схем преференций.

3 Komuro N. Japan's Generalised System of Preferences: An Oriental Pandora's Box. URL: http://www.worldtradelaw.net/articles/komuropreferences.pdf 
Отдельные НРС. В 2010 г. средние тарифные ставки, применяемые к отдельным НРС, варьируются в широких пределах на определенных рынках (табл. 7). Однако это частично объясняется отсутствием торговли по некоторым товарным позициям (это в меньшей степени относится к странам, где торговля более диверсифицирована и различиями между отдельными странами).

\section{Таблицза 5}

\section{Использование преференций в 2009 г., \%}

\begin{tabular}{|c|c|c|c|}
\hline \multirow[b]{2}{*}{ Импортер } & \multicolumn{2}{|c|}{ Доля общего импорта из НРС } & \multirow{2}{*}{$\begin{array}{l}\text { Доля товаров, } \\
\text { ввезенных } \\
\text { с использованием } \\
\text { преференций } \\
\text { по отношению } \\
\text { к импорту, } \\
\text { для которого } \\
\text { действуют } \\
\text { преференции }\end{array}$} \\
\hline & $\begin{array}{l}\text { Действуют } \\
\text { преференции }\end{array}$ & $\begin{array}{l}\text { Ввезено с } \\
\text { использованием } \\
\text { преференций }\end{array}$ & \\
\hline Канада & 36,7 & 32,7 & 89,1 \\
\hline ЕС (заниженная оценка) & 48,2 & 40,1 & 81,9 \\
\hline ЕС (завышенная оценка) & 49 & 41,4 & 85,9 \\
\hline США & 69,5 & 60,9 & 87,5 \\
\hline \multicolumn{4}{|c|}{$\begin{array}{l}\text { Примечания. 1. Нельзя напрямую сравнивать результаты по разным преференци- } \\
\text { альным схемам, вследствие различий в охвате и отчетах, Нижний порог оценки в } \\
\text { ЕС включает ОСП и прочие преференциальные схемы, которые были применены в } \\
\text { странах ЕС вследствие различий как в самих схемах, так и в способах их осущест- } \\
\text { вленпя. 2. Завышенная оценка получена на основе предположения, что товар с неиз- } \\
\text { вестным режимом вводится как преференциальный, а заниженная оценка - на ос- } \\
\text { нове предположения, что такой товар вводится в рамках РНБ. 3. Результаты в США } \\
\text { включают все преференциальные схемы: АGОА. Инициативу по странам Карибского } \\
\text { бассейна. ОСП и ОСП для наименее развитых развивающихся стран-бенефициаров } \\
\text { (ОСП НРСБ). 4. Япония не охватывается в оригинальной таблице в документе ВТО, } \\
\text { на основе которого построена данная таблица. }\end{array}$} \\
\hline
\end{tabular}

Источник: [4]. 


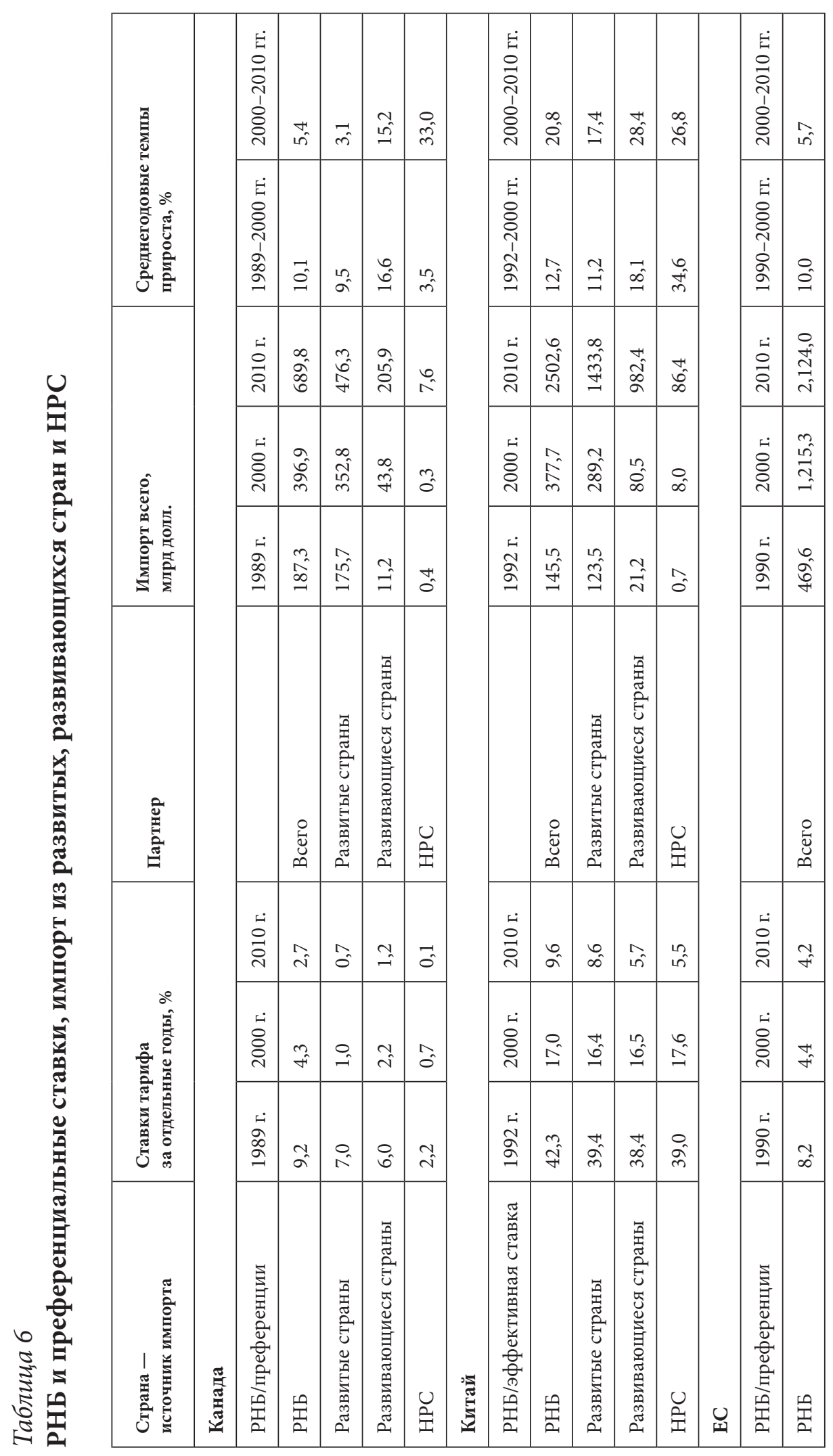




\begin{tabular}{|c|c|c|c|c|c|c|c|c|c|c|c|c|c|c|}
\hline$\stackrel{\vec{m}}{m}$ & $\stackrel{H}{n}$ & $\sigma_{0}^{0}$ & & 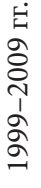 & $\hat{\imath}$ & $\stackrel{12}{\underbrace{2}}$ & $\begin{array}{l}0 \\
\hat{n}\end{array}$ & $\hat{i}_{i}^{m}$ & & 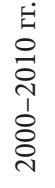 & $\hat{i}$ & $\stackrel{n}{\underset{f}{f}}$ & $\stackrel{\sim}{\sim}$ & $\mathrm{L}^{2}$ \\
\hline$\vec{n}$ & $\stackrel{\vec{n}}{\stackrel{n}{n}}$ & $\vec{f}$ & & 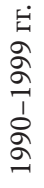 & $\overrightarrow{ \pm 灬}$ & $\overrightarrow{\mathfrak{I}}$ & $\stackrel{+}{a}$ & $\stackrel{m}{\stackrel{\jmath}{\jmath}}$ & & 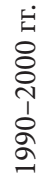 & $\stackrel{m}{m}$ & $\stackrel{+}{\hat{\imath}}$ & $\stackrel{\infty}{\sigma}$ & $\begin{array}{l}0 \\
\hat{1}\end{array}$ \\
\hline 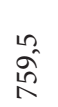 & $\begin{array}{l}0 \\
\hat{\mathbb{N}} \\
\hat{n} \\
\hat{-}\end{array}$ & $\begin{array}{l}\hat{\mathfrak{f}} \\
\hat{f}\end{array}$ & & $\begin{array}{l}\dot{\Delta} \\
\text { ڤे̀े }\end{array}$ & $\hat{\stackrel{8}{0}}$ & $\stackrel{m}{m} \stackrel{m}{n}_{n}^{n}$ & $\begin{array}{l}\text { f̂ } \\
\hat{f}\end{array}$ & $\cong$ & & $\begin{array}{l}\dot{0} \\
\stackrel{\circ}{\circ} \\
\stackrel{\sim}{1}\end{array}$ & $\stackrel{\text { }}{\stackrel{\sim}{\sim}}$ & $\hat{i}$ & $\overrightarrow{\mathrm{fH}}$ & $\stackrel{\circ}{-}$ \\
\hline ले & $\overrightarrow{\text { ôे }}$ & $\hat{\widetilde{N}}$ & & बे & $\begin{array}{l}0 \\
\hat{f}\end{array}$ & $\begin{array}{l}\text { in } \\
\hat{\lambda}\end{array}$ & $\hat{\imath े}$ & $\stackrel{\sim}{\approx}$ & & $\begin{array}{l}\dot{\leftrightarrow} \\
\text { ठे }\end{array}$ & ले & $\begin{array}{l}0 \\
\hat{I}\end{array}$ & $\hat{\tilde{F}}$ & H' \\
\hline$\underset{\hat{\sim}}{\stackrel{\leftrightarrow}{\sim}}$ & $\begin{array}{l}\hat{0} \\
\stackrel{0}{0}\end{array}$ & $\hat{\vec{m}}$ & & $\begin{array}{l}\dot{0} \\
\text { ڤे }\end{array}$ & $\stackrel{N}{\mathcal{E}}$ & $\begin{array}{l}0 \\
\stackrel{0}{0}\end{array}$ & $\hat{n}$ & $\begin{array}{l}+ \\
0\end{array}$ & & $\begin{array}{l}\dot{0} \\
\text { م }\end{array}$ & $\begin{array}{l}0 \\
\stackrel{\infty}{\stackrel{+}{I}}\end{array}$ & $\stackrel{0}{0}$ & $\stackrel{\cong}{\cong}$ & $\hat{0}$ \\
\hline 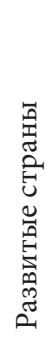 & 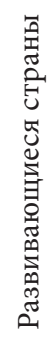 & 㟋 & & & $\begin{array}{l}0 \\
\text { Uू̆ } \\
\infty\end{array}$ & 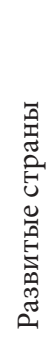 & 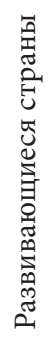 & 岂 & & & $\begin{array}{l}0 \\
\text { ¿্ّ } \\
\infty\end{array}$ & 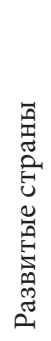 & 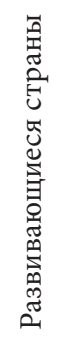 & 号 \\
\hline$\stackrel{\infty}{\infty}$ & $\hat{o}$ & $\ddot{O}_{0}$ & & ठे & $\stackrel{\infty}{=}$ & $\stackrel{m}{n}$ & $\stackrel{6}{f}$ & $\hat{o}$ & & $\stackrel{\circ}{\circ}$ & $\vec{m}$ & $\stackrel{\sim}{\rightarrow}$ & $\stackrel{\infty}{\rightarrow}$ & ? \\
\hline$\Rightarrow$ & $\stackrel{\sim}{\approx}$ & $\stackrel{0}{0}$ & & Әे & $\stackrel{\text { mे }}{m^{2}}$ & & $\stackrel{H}{a}$ & $\vec{\infty}$ & & 宫 & $\stackrel{H}{m}$ & $\stackrel{i}{i}$ & $\stackrel{\text { Ln }}{i}$ & L \\
\hline ?h & ô & ô & & $\begin{array}{l}\dot{0} \\
\text { مे }\end{array}$ & $\begin{array}{l}0 \\
\dot{\infty}\end{array}$ & & & & & $\begin{array}{l}\dot{0} \\
\text { م }\end{array}$ & $\stackrel{m}{*}$ & $\tilde{m}^{n}$ & $\stackrel{\dot{m}}{n}$ & $\hat{a}$ \\
\hline 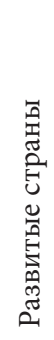 & 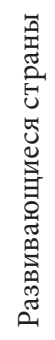 & $\begin{array}{l}\text { U } \\
\text { 界 }\end{array}$ & 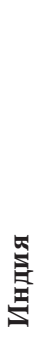 & 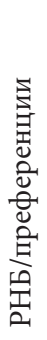 & 虽 & 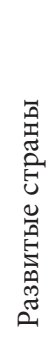 & 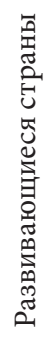 & 岂 & 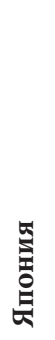 & 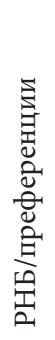 & 惡 & 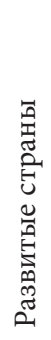 & 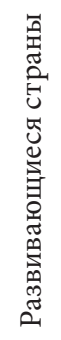 & 堊 \\
\hline
\end{tabular}




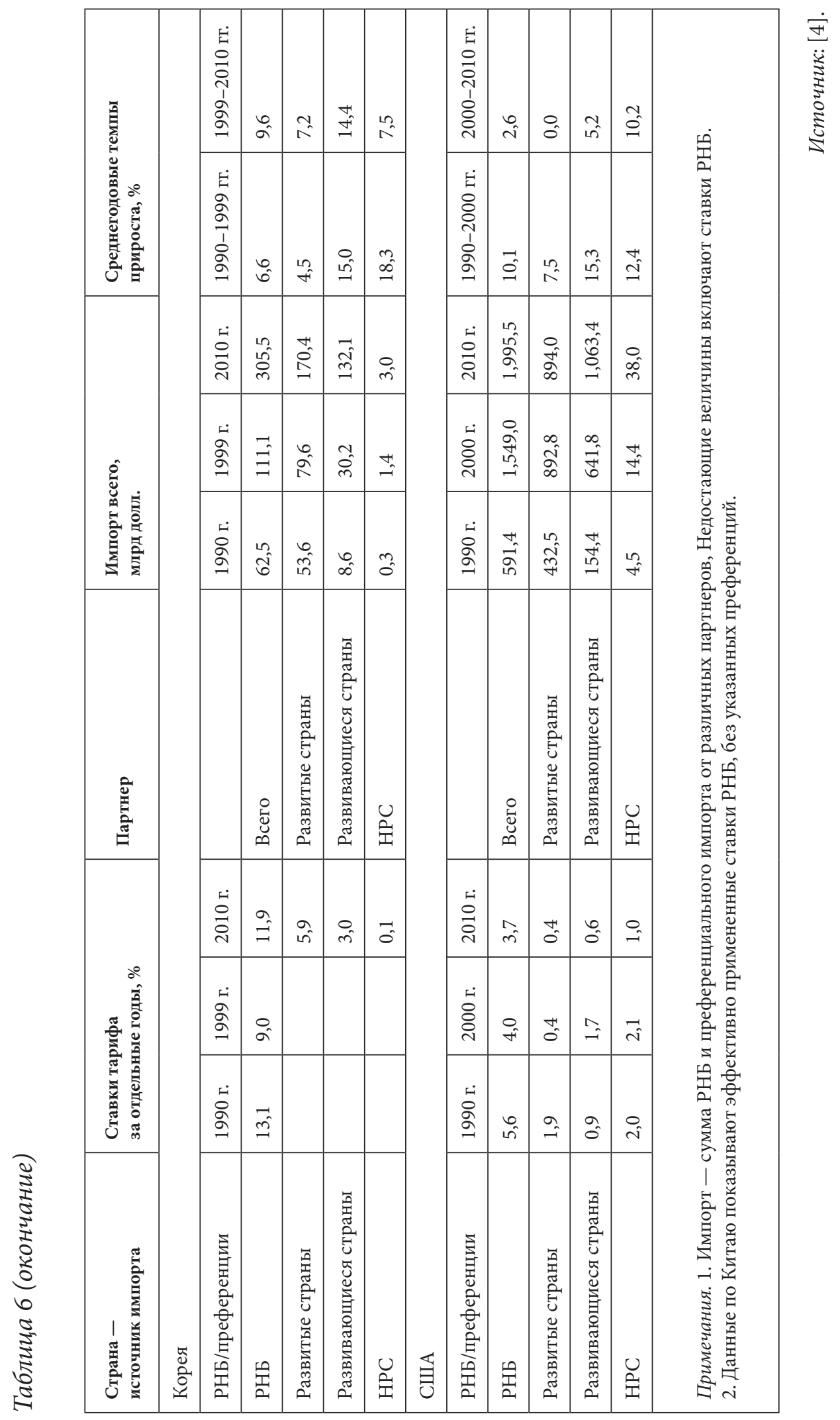


Таблиияа 7

Средние ставки, применяемые к товарам, которыми осуществляется фактическая торговля отдельными странамидонорами в отношении отдельных бенефициаров национальных систем преференций в 2010 г., \%

\begin{tabular}{|c|c|c|c|c|c|c|c|}
\hline HPC & Канада & Китай & EC & Индия & Япония & Корея & США \\
\hline Афганистан & 0,0 & 7,2 & 1,1 & $\mathrm{H} / \mathrm{T}$ & 1,0 & 0,9 & 1,4 \\
\hline Ангола & 8,0 & 4,2 & 1,6 & $\mathrm{H} / \mathrm{T}$ & 0,0 & 1,5 & 0,8 \\
\hline Бангладеш & 0,0 & 8,9 & 0,8 & $\mathrm{H} / \mathrm{T}$ & 0,3 & 4,6 & 5,9 \\
\hline Бенин & 0,0 & 2,9 & 1,0 & $\mathrm{H} / \mathrm{T}$ & 0,0 & 106,3 & 0,7 \\
\hline Бутан & 0,0 & 1,9 & 1,2 & 1,0 & 0,0 & 19,4 & 2,2 \\
\hline Буркина Фасо & 0,0 & 5,9 & 1,1 & $\mathrm{H} / \mathrm{T}$ & 0,3 & 1,8 & 1,8 \\
\hline Бурунди & 0,0 & 1,1 & 0,0 & $\mathrm{H} / \mathrm{T}$ & 0,0 & 0,0 & 3,8 \\
\hline Камбоджа & 0,0 & 0,7 & 0,8 & $\mathrm{H} / \mathrm{T}$ & 0,5 & 12,2 & 7,8 \\
\hline $\begin{array}{l}\text { Центрально- } \\
\text { африканская } \\
\text { Республика }\end{array}$ & 0,0 & 4,5 & 1,4 & $\mathrm{H} / \mathrm{T}$ & 0,0 & 0,0 & 0,2 \\
\hline Чад & 0,0 & 5,2 & 1,2 & $\mathrm{H} / \mathrm{T}$ & 0,0 & 0,0 & 0,0 \\
\hline Коморские острова & 0,0 & 10,6 & 0,0 & $\mathrm{H} / \mathrm{T}$ & 1,5 & 10,0 & 0,0 \\
\hline $\begin{array}{l}\text { Демократическая } \\
\text { Республика Конго }\end{array}$ & 0,0 & 5,6 & 1,2 & $\mathrm{H} / \mathrm{T}$ & 0,0 & 3,0 & 0,6 \\
\hline Джибути & 0,0 & 7,6 & 1,2 & $\mathrm{H} / \mathrm{T}$ & 0,0 & 0,0 & 0,0 \\
\hline Восточный Тимор & 2,8 & 1,4 & 0,7 & $\mathrm{H} / \mathrm{T}$ & 0,0 & 1,5 & $\mathrm{H} / \mathrm{T}$ \\
\hline $\begin{array}{l}\text { Экваториальная } \\
\text { Гвинея }\end{array}$ & 0,0 & 0,6 & 1,5 & $\mathrm{H} / \mathrm{T}$ & 0,7 & 0,0 & 0,0 \\
\hline Эритрея & 3,3 & 2,2 & 1,1 & $\mathrm{H} / \mathrm{T}$ & 0,0 & 0,0 & 5,0 \\
\hline $\begin{array}{l}\text { Эфиопия } \\
\text { (без Эритреи) }\end{array}$ & 0,0 & 6,7 & 1,0 & 13,9 & 0,0 & 31,8 & 0,5 \\
\hline Гамбия & 0,0 & 6,2 & 1,0 & $\mathrm{H} / \mathrm{T}$ & 0,0 & 0,0 & 0,6 \\
\hline Гвинея & 0,0 & 5,9 & 1,1 & $\mathrm{H} / \mathrm{T}$ & 0,3 & 4,8 & 1,3 \\
\hline Гвинея-Биссау & 0,0 & 2,8 & 1,5 & $\mathrm{H} / \mathrm{T}$ & $\mathrm{H} / \mathrm{T}$ & 3,3 & 0,0 \\
\hline Гаити & 0,0 & 10,2 & 0,0 & $\mathrm{H} / \mathrm{T}$ & 0,0 & 3,4 & 4,3 \\
\hline Кирибати & 0,0 & 2,5 & 1,0 & $\mathrm{H} / \mathrm{T}$ & $\mathrm{H} / \mathrm{T}$ & 1,3 & 0,0 \\
\hline Лаос & 0,0 & 2,2 & 0,6 & $\mathrm{H} / \mathrm{T}$ & 0,7 & 14,2 & 7,4 \\
\hline Лесото & 0,0 & 7,1 & 0,0 & $\mathrm{H} / \mathrm{T}$ & 0,0 & 2,2 & 0,2 \\
\hline
\end{tabular}


Таблица 7 (окончание)

\begin{tabular}{|c|c|c|c|c|c|c|c|}
\hline HPC & Канада & Китай & EC & Индия & Япония & Корея & США \\
\hline Либерия & 0,0 & 2,5 & 1,1 & $\mathrm{H} / \mathrm{T}$ & 1,1 & 0,8 & 1,6 \\
\hline Мадагаскар & 0,0 & 7,4 & 0,0 & 13,6 & 0,0 & 6,1 & 0,8 \\
\hline Малави & 0,0 & 4,8 & 0,8 & 19,9 & 0,0 & 28,0 & 3,1 \\
\hline Мали & 0,0 & 5,4 & 1,0 & 9,6 & 0,0 & 19,7 & 1,8 \\
\hline Мавритания & 0,0 & 5,3 & 1,0 & $\mathrm{H} / \mathrm{T}$ & 0,9 & 4,9 & 2,1 \\
\hline Мозамбик & 0,0 & 3,0 & 0,0 & $\mathrm{H} / \mathrm{T}$ & 0,0 & 11,7 & 1,2 \\
\hline Мьянма & 0,0 & 1,2 & 6,8 & $\mathrm{H} / \mathrm{T}$ & 0,2 & 14,2 & 1,9 \\
\hline Непал & 0,0 & 11,3 & 0,8 & $\mathrm{H} / \mathrm{T}$ & 0,2 & 5,4 & 5,5 \\
\hline Нигер & 0,0 & 5,9 & 1,4 & 26,0 & 0,0 & 1,2 & 0,1 \\
\hline Руанда & 0,0 & 5,5 & 0,0 & 6,7 & 0,0 & 0,9 & 0,3 \\
\hline Самоа & 0,0 & 8,7 & 2,2 & $\mathrm{H} / \mathrm{T}$ & 0,0 & 7,9 & 1,6 \\
\hline $\begin{array}{l}\text { Сан-Томе и } \\
\text { Принсипи }\end{array}$ & 0,0 & 5,9 & 1,3 & $\mathrm{H} / \mathrm{T}$ & 0,0 & 12,8 & 0,0 \\
\hline Сенегал & 4,0 & 5,8 & 1,0 & 7,9 & 0,9 & 5,4 & 1,3 \\
\hline Сьерра Леоне & 0,0 & 4,4 & 1,2 & $\mathrm{H} / \mathrm{T}$ & 0,0 & 3,1 & 0,2 \\
\hline $\begin{array}{l}\text { Соломоновы } \\
\text { острова }\end{array}$ & 0,0 & 7,0 & 1,2 & $\mathrm{H} / \mathrm{T}$ & 0,7 & 3,5 & 0,0 \\
\hline Сомали & 0,0 & 4,2 & 0,5 & $\mathrm{H} / \mathrm{T}$ & 0,3 & $\mathrm{H} / \mathrm{T}$ & 1,0 \\
\hline Судан & 0,0 & 5,1 & 1,2 & 11,9 & 0,0 & 22,1 & 0,6 \\
\hline Танзания & 0,0 & 4,9 & 0,0 & $\mathrm{H} / \mathrm{T}$ & 0,0 & 1,7 & 0,5 \\
\hline Того & 0,0 & 6,6 & 0,9 & $\mathrm{H} / \mathrm{T}$ & 0,1 & 2,7 & 0,8 \\
\hline Тувалу & $\mathrm{H} / \mathrm{T}$ & 0,0 & 1,1 & $\mathrm{H} / \mathrm{T}$ & 0,0 & 0,0 & 0,0 \\
\hline Уганда & 0,0 & 4,3 & 0,0 & 15,7 & 0,0 & 3,5 & 2,1 \\
\hline Вануату & 0,0 & 3,3 & 1,0 & $\mathrm{H} / \mathrm{T}$ & 0,2 & 5,3 & 0,1 \\
\hline Йемен & 0,0 & 7,6 & 1,0 & $\mathrm{H} / \mathrm{T}$ & 0,7 & 7,6 & 2,8 \\
\hline Замбия & 0,0 & 4,2 & 0,0 & 6,8 & 0,0 & 1,1 & 2,4 \\
\hline В среднем НРС & 0,3 & 5,5 & 0,9 & 12,4 & 0,3 & 8,8 & 3,2 \\
\hline
\end{tabular}

Примечания. 1. Нет торговли, зарегистрированной с данной НРС. 2. Среднее - это простое среднее арифметическое только для поставок с регистрируемой торговлей.

3. Корея импортировала из Бенина масличных семян на сумму около 2200 долл. по средней ставке $630 \%$, искажая таким образом простую среднюю. Большую часть корейского импорта из Бенина составляют медь и алюминиевый лом по нулевой тарифной ставке.

Источник: WITS. 
Кроме того, можно отметить значительный разброс в показателе отношения тарифных позиций, не облагаемых пошлинами, к общему количеству тарифных позиций на рассматриваемых рынках (табл. 8 и 9, охватывающие 2000 и 2010 гг. соответственно) . Как и ожидалось, наибольший охват, увеличившийся за 10 лет, отмечается в развитых странах, небольшой охват некоторых НРС таких как Бангладеш, - на рынках США и Канады, что приписывается к исключению импорта текстильных товаров. Другие примеры небольшого охвата ассоциируются с политическими факторами, как было сказано выше.

\section{Таблица 8}

Отношение беспошлинных тарифных линий к общему количеству тарифных линий, по которым осуществляется импорт из страны-партнера в 2000 г., \%

\begin{tabular}{|l|l|l|l|l|l|l|l|}
\hline нРС & Канада & Китай & EС & Индия & Япония & Корея & СшА \\
\hline Афганистан & 92,7 & 2,1 & 99,3 & 0,0 & 100,0 & 0,0 & 17,9 \\
\hline Ангола & 100,0 & 0,0 & 94,3 & 0,0 & 28,6 & 0,0 & 100,0 \\
\hline Бангладеш & 64,9 & 2,9 & 92,7 & 3,8 & 88,1 & 0,0 & 45,0 \\
\hline Бенин & 64,7 & 16,7 & 97,2 & 28,6 & 100,0 & 0,0 & 88,9 \\
\hline Бутан & 100,0 & & 100,0 & 2,0 & 76,9 & 100,0 & 34,8 \\
\hline Буркина Фасо & 100,0 & & 89,5 & 0,0 & 79,4 & 0,0 & 54,7 \\
\hline Бурунди & 100,0 & 50,0 & 98,2 & & 87,5 & & 92,0 \\
\hline Камбоджа & 50,0 & 12,7 & 91,8 & 0,0 & 68,5 & 1,5 & 13,5 \\
\hline $\begin{array}{l}\text { Центрально- } \\
\text { африканская } \\
\text { Республика }\end{array}$ & 74,3 & 0,0 & 80,4 & & 100,0 & 0,0 & 84,7 \\
\hline Чад & 95,2 & 0,0 & 96,1 & & 100,0 & & 100,0 \\
\hline Коморские острова & 100,0 & 0,0 & 98,9 & & 83,3 & & 100,0 \\
\hline $\begin{array}{l}\text { Демократическая } \\
\text { Республика Конго }\end{array}$ & & 14,3 & 93,7 & 0,0 & 75,0 & 20,0 & 85,0 \\
\hline Джибути & 100,0 & 0,0 & 82,9 & 50,0 & & & 100,0 \\
\hline $\begin{array}{l}\text { Экваториальная } \\
\text { Гвинея }\end{array}$ & 22,2 & 0,0 & 100,0 & & 27,8 & 0,0 & 100,0 \\
\hline Эритрея & 89,6 & 0,0 & 97,1 & 0,0 & 51,5 & 0,0 & 83,1 \\
\hline $\begin{array}{l}\text { Эфиопия } \\
\text { (без Эритреи) }\end{array}$ & 93,8 & 10,8 & 90,1 & 14,3 & 100,0 & 0,0 & 92,1 \\
\hline Гамбия & 97,6 & & 99,6 & 50,0 & 38,1 & 0,0 & 52,9 \\
\hline Гвинея & & & 99,1 & & 79,2 & 0,0 & 15,8 \\
\hline
\end{tabular}


Таблица 8 (окончание)

\begin{tabular}{|c|c|c|c|c|c|c|c|}
\hline HPC & Канада & Китай & EC & Индия & Япония & Корея & США \\
\hline Гвинея-Биссау & 100,0 & 0,0 & 98,8 & 50,0 & & 0,0 & 100,0 \\
\hline Гаити & 78,6 & 0,0 & 95,8 & & 88,1 & 0,0 & 70,9 \\
\hline Кирибати & 100,0 & 0,0 & 100,0 & & 11,1 & & 100,0 \\
\hline Лаос & 50,8 & 6,0 & 79,4 & & 92,9 & 0,0 & 2,3 \\
\hline Лесото & 46,2 & 0,0 & 100,0 & & 100,0 & & 8,8 \\
\hline Либерия & 100,0 & 10,0 & 86,6 & 0,0 & 47,1 & 2,6 & 52,3 \\
\hline Мадагаскар & 77,3 & 3,4 & 97,1 & 4,8 & 91,9 & 0,0 & 50,9 \\
\hline Малави & 84,0 & & 83,0 & 0,0 & 80,0 & 0,0 & 66,7 \\
\hline Мали & 98,0 & 0,0 & 96,8 & 0,0 & 100,0 & 0,0 & 76,8 \\
\hline Мавритания & 80,8 & 14,3 & 99,6 & 0,0 & 62,0 & 0,0 & 17,0 \\
\hline Мозамбик & 71,4 & 0,0 & 88,8 & 10,0 & 83,3 & 0,0 & 96,8 \\
\hline Мьянма & 46,2 & 10,5 & 89,8 & 2,2 & 72,3 & 1,7 & 21,6 \\
\hline Непал & 68,9 & 0,6 & 98,9 & 1,3 & 95,2 & 6,8 & 39,5 \\
\hline Нигер & 81,2 & & 98,5 & 0,0 & 92,3 & 0,0 & 85,8 \\
\hline Руанда & 100,0 & 16,7 & 100,0 & & 80,0 & 0,0 & 84,4 \\
\hline Самоа & 66,7 & 0,0 & 72,9 & 0,0 & 47,1 & 0,0 & 70,9 \\
\hline $\begin{array}{l}\text { Сан-Томе и } \\
\text { Принсипи }\end{array}$ & 100,0 & & 100,0 & & 64,7 & 0,0 & 98,1 \\
\hline Сенегал & 69,2 & 5,6 & 97,3 & 6,7 & 30,8 & 3,7 & 43,5 \\
\hline Сьерра Леоне & 80,0 & 21,4 & 95,0 & 0,0 & 81,8 & 0,0 & 67,2 \\
\hline $\begin{array}{l}\text { Соломоновы } \\
\text { острова }\end{array}$ & 100,0 & 0,0 & 100,0 & 0,0 & 57,9 & 0,0 & 88,9 \\
\hline Сомали & 100,0 & 0,0 & 97,2 & 57,1 & 17,2 & 0,0 & 92,1 \\
\hline Судан & 100,0 & 4,8 & 96,1 & 30,8 & 45,3 & 0,0 & 85,7 \\
\hline Танзания & 87,5 & 8,0 & 99,0 & 9,5 & 77,5 & 0,0 & 89,9 \\
\hline Того & 59,3 & 20,0 & 96,0 & 0,0 & 100,0 & 0,0 & 76,5 \\
\hline Тувалу & & & 100,0 & & & & 20,0 \\
\hline Уганда & 96,4 & 0,0 & 98,5 & 26,7 & 35,4 & 0,0 & 86,7 \\
\hline Вануату & 100,0 & 6,1 & 96,2 & 0,0 & 41,0 & 0,0 & 100,0 \\
\hline Йемен & 100,0 & 0,0 & 99,9 & 7,4 & 45,1 & 0,0 & 90,9 \\
\hline Замбия & 96,4 & 14,3 & 98,9 & 0,0 & 100,0 & 0,0 & 81,7 \\
\hline В среднем НРС & 75,2 & 6,3 & 94,9 & 4,0 & 72,7 & 1,3 & 55,4 \\
\hline
\end{tabular}

Источник: WITS. 
Таблиияа 9

\section{Отношение беспошлинных тарифных линий к общему количеству тарифных линий, по которым осуществляется импорт из страны-партнера в 2010 г., \%}

\begin{tabular}{|c|c|c|c|c|c|c|c|}
\hline HPC & Канада & Китай & EC & Индия & Япония & Корея & США \\
\hline Афганистан & 100,0 & 39,5 & 62,4 & & 90,3 & 83,1 & 81,9 \\
\hline Ангола & 36,4 & 64,7 & 46,7 & & 100,0 & 79,4 & 95,6 \\
\hline Бангладеш & 99,2 & 15,2 & 73,1 & & 96,7 & 72,1 & 56,0 \\
\hline Бенин & 100,0 & 88,7 & 62,1 & & 100,0 & 61,5 & 96,7 \\
\hline Бутан & 100,0 & 87,5 & 53,8 & 98,2 & 100,0 & 27,3 & 88,0 \\
\hline Буркина Фасо & 100,0 & 5,9 & 57,6 & & 95,5 & 70,0 & 88,0 \\
\hline Бурунди & 100,0 & 93,3 & 100,0 & & 100,0 & 100,0 & 78,6 \\
\hline Камбоджа & 99,3 & 94,8 & 72,3 & & 95,8 & 74,1 & 40,1 \\
\hline $\begin{array}{l}\text { Центрально- } \\
\text { африканская } \\
\text { Республика }\end{array}$ & 100,0 & 45,2 & 49,5 & & 100,0 & 100,0 & 94,8 \\
\hline Чад & 100,0 & 44,0 & 46,5 & & 100,0 & 100,0 & 100,0 \\
\hline $\begin{array}{l}\text { Коморские } \\
\text { острова }\end{array}$ & 100,0 & 18,2 & 100,0 & & 42,9 & 33,3 & 100,0 \\
\hline $\begin{array}{l}\text { Демократическая } \\
\text { Республика Конго }\end{array}$ & 100,0 & 41,2 & 58,0 & & 100,0 & 80,2 & 91,5 \\
\hline Джибути & 100,0 & 41,6 & 50,1 & & & 100,0 & 100,0 \\
\hline Восточный Тимор & 68,6 & 78,1 & 71,8 & & 100,0 & 25,0 & \\
\hline $\begin{array}{l}\text { Экваториальная } \\
\text { Гвинея }\end{array}$ & 100,0 & 73,3 & 41,6 & & 100,0 & 100,0 & 100,0 \\
\hline Эритрея & 65,8 & 70,7 & 67,5 & & 100,0 & 100,0 & 66,7 \\
\hline $\begin{array}{l}\text { Эфиопия } \\
\text { (без Эритреи) }\end{array}$ & 98,7 & 31,1 & 61,4 & 6,4 & 80,8 & 50,4 & 91,1 \\
\hline Гамбия & 100,0 & 59,0 & 68,3 & & 100,0 & 100,0 & 91,1 \\
\hline Гвинея & 100,0 & 58,8 & 68,8 & & 86,0 & 63,0 & 91,9 \\
\hline Гвинея-Биссау & 100,0 & 83,3 & 65,7 & & & 80,0 & 100,0 \\
\hline Гаити & 98,4 & 14,5 & 91,2 & & 100,0 & 66,1 & 71,5 \\
\hline Кирибати & 100,0 & 80,0 & 44,4 & & 100,0 & 31,7 & 100,0 \\
\hline Лаос & 100,0 & 91,5 & 79,2 & & 95,1 & 79,8 & 22,9 \\
\hline Лесото & 100,0 & 50,0 & 100,0 & & 100,0 & 68,4 & 89,3 \\
\hline Либерия & 95,6 & 81,8 & 50,6 & & 74,1 & 69,6 & 64,3 \\
\hline Мадагаскар & 98,4 & 41,0 & 100,0 & 2,2 & 97,8 & 81,9 & 85,0 \\
\hline Малави & 94,4 & 56,6 & 68,9 & 25,7 & 100,0 & 87,0 & 91,9 \\
\hline Мали & 100,0 & 64,6 & 66,0 & 7,3 & 100,0 & 67,7 & 74,1 \\
\hline
\end{tabular}


Таблица 9 (окончание)

\begin{tabular}{|l|l|l|l|l|l|l|l|}
\hline нРС & Канада & Китай & EC & Индия & Япония & Корея & СшА \\
\hline Мавритания & 97,8 & 68,4 & 67,8 & & 79,7 & 41,6 & 65,6 \\
\hline Мозамбик & 100,0 & 69,6 & 93,2 & & 100,0 & 64,3 & 98,2 \\
\hline Мьянма & 100,0 & 93,6 & 17,9 & & 92,5 & 63,9 & 25,0 \\
\hline Непал & 99,4 & 13,4 & 74,4 & & 98,0 & 82,5 & 50,5 \\
\hline Нигер & 100,0 & 45,0 & 49,3 & 0,0 & 100,0 & 88,5 & 88,1 \\
\hline Руанда & 100,0 & 49,1 & 100,0 & 1,8 & 100,0 & 93,8 & 88,2 \\
\hline Самоа & 100,0 & 30,0 & 67,0 & & 93,8 & 68,8 & 84,7 \\
\hline $\begin{array}{l}\text { Сан-Томе } \\
\text { и Принсипи }\end{array}$ & 100,0 & 33,3 & 45,0 & & 100,0 & 38,9 & 81,8 \\
\hline Сенегал & 51,7 & 43,2 & 70,8 & 7,7 & 80,9 & 67,3 & 84,9 \\
\hline Сьерра Леоне & 100,0 & 59,3 & 61,2 & & 100,0 & 31,6 & 93,6 \\
\hline $\begin{array}{l}\text { Соломоновы } \\
\text { острова }\end{array}$ & 100,0 & 58,1 & 51,4 & & 100,0 & 90,5 & 100,0 \\
\hline Сомали & 100,0 & 50,0 & 79,9 & & 92,9 & & 95,0 \\
\hline Судан & 100,0 & 32,9 & 45,6 & 11,9 & 92,5 & 68,1 & 76,9 \\
\hline Танзания & 97,6 & 45,8 & 95,4 & & 99,0 & 84,9 & 93,8 \\
\hline Того & 100,0 & 60,6 & 70,6 & & 100,0 & 37,7 & 88,4 \\
\hline Тувалу & 100,0 & 52,7 & 93,0 & 12,4 & 100,0 & 89,8 & 84,8 \\
\hline Уганда & 98,8 & 63,9 & 95,8 & 3,8 & 96,3 & 44,2 & 85,7 \\
\hline Вануату & 100,0 & 48,0 & 67,1 & & 88,5 & 77,6 & 75,0 \\
\hline Йемен & 100,0 & 28,9 & 63,4 & & 85,5 & 74,5 & 57,1 \\
\hline Замбия & 52,5 & 70,7 & 9,3 & 94,8 & 71,0 & 72,0 \\
\hline В среднем НРС & 100,0 & 60,5 & & 100,0 & 100,0 & 100,0 \\
\hline \begin{tabular}{l} 
Примечания. 1. По Индии и Корее - представлены данные за 1999 г. \\
\hline Не содержит позиций с зарегистрированной торговлей.
\end{tabular} \\
\hline
\end{tabular}

Источник: WITS.

Иногда сложно точно интерпретировать данные. География, обеспеченность ресурсами и меняющиеся условия торговли - факторы, которые могут повлиять на структуру торговли.

В показателе беспошлинного импорта из определенных НРС отмечен значительный разброс в отношении общих объемов торговли (табл. 10 и 11, охватывающие 2000 и 2010 гг.). В целом охват торговли расширился на всех рынках, за исключением ЕС, где был отмечен небольшой спад с 99,7 до 96,3\%. 
В развивающихся странах наблюдался подъем средней ставки: с 0,5 до 96,9\% в Китае, с 16,7 до 58,7\% в Индии и с 2,2 до 79,8\% в Корее. На эти данные также влияет множество отдельных факторов, среди которых следует назвать охват тарифных позиций в стране, структуру и условия торговли. Например, данные о Восточном Тиморе есть за 2010 г., но их нет за 2000 г.

Таблица 10

Показатель отношения беспошлинного импорта к общему импорту торгового партнера в 2000 г., \%

\begin{tabular}{|c|c|c|c|c|c|c|c|}
\hline HPC & Канада & Китай & EC & Индия & Япония & Корея & США \\
\hline Афганистан & 94,3 & 0,0 & 100,0 & 0,0 & 100,0 & 0,0 & 84,1 \\
\hline Ангола & 100,0 & 0,0 & 100,0 & 0,0 & 95,5 & 0,0 & 100,0 \\
\hline Бангладеш & 10,2 & 0,0 & 99,7 & 0,2 & 72,2 & 0,0 & 8,2 \\
\hline Бенин & 93,9 & 0,0 & 99,9 & 50,0 & 100,0 & 0,0 & 99,6 \\
\hline Бутан & 100,0 & & 100,0 & 0,1 & 65,9 & 100,0 & 60,1 \\
\hline Буркина Фасо & 100,0 & & 98,9 & 0,0 & 99,5 & 0,0 & 97,7 \\
\hline Бурунди & 100,0 & 98,7 & 100,0 & & 99,5 & & 99,9 \\
\hline Камбоджа & 2,0 & 0,0 & 100,0 & 0,0 & 89,1 & 57,7 & 0,5 \\
\hline $\begin{array}{l}\text { Центрально- } \\
\text { африканская } \\
\text { Республика }\end{array}$ & 99,5 & 0,0 & 100,0 & & 100,0 & 0,0 & 32,1 \\
\hline Чад & 75,2 & 0,0 & 100,0 & & 100,0 & & 100,0 \\
\hline Коморские острова & 100,0 & 0,0 & 100,0 & & 93,6 & & 100,0 \\
\hline $\begin{array}{l}\text { Демократическая } \\
\text { Республика Конго }\end{array}$ & & 21,5 & 99,9 & 0,0 & 99,6 & 0,0 & 100,0 \\
\hline Джибути & 100,0 & 0,0 & 99,8 & 79,2 & 15,0 & & 100,0 \\
\hline $\begin{array}{l}\text { Экваториальная } \\
\text { Гвинея }\end{array}$ & 0,0 & 0,0 & 100,0 & & & 0,0 & 100,0 \\
\hline Эритрея & & & 99,4 & & 100,0 & 0,0 & 46,5 \\
\hline $\begin{array}{l}\text { Эфиопия (без } \\
\text { Эритреи) }\end{array}$ & 94,5 & 76,7 & 100,0 & 38,2 & 100,0 & 0,0 & 89,6 \\
\hline Гамбия & 94,0 & & 99,3 & 49,6 & 20,0 & 0,0 & 70,9 \\
\hline Гвинея & 99,8 & 0,0 & 100,0 & 0,0 & 11,1 & 0,0 & 99,8 \\
\hline Гвинея Биссау & 100,0 & 0,0 & 99,7 & 98,3 & & 0,0 & 100,0 \\
\hline Гаити & 21,6 & 0,0 & 98,9 & & 95,1 & 0,0 & 16,6 \\
\hline Кирибати & 100,0 & 0,0 & 100,0 & & 0,2 & & 100,0 \\
\hline Лаос & 5,8 & 0,1 & 99,8 & & 99,7 & 0,0 & 0,1 \\
\hline
\end{tabular}


Таблица 10 (окончание)

\begin{tabular}{|c|c|c|c|c|c|c|c|}
\hline HPC & Канада & Китай & EC & Индия & Япония & Корея & США \\
\hline Лесото & 0,0 & 0,0 & 100,0 & & 100,0 & & 0,0 \\
\hline Либерия & 100,0 & 0,0 & 100,0 & 0,0 & 57,3 & 99,1 & 97,8 \\
\hline Мадагаскар & 70,5 & 0,1 & 99,8 & 29,0 & 35,8 & 0,0 & 27,4 \\
\hline Малави & 98,8 & & 100,0 & 0,0 & 98,0 & 0,0 & 20,8 \\
\hline Мали & 99,1 & 0,0 & 97,3 & 0,0 & 100,0 & 0,0 & 95,9 \\
\hline Мавритания & 98,4 & 0,0 & 100,0 & 0,0 & 1,4 & 0,0 & 44,8 \\
\hline Мозамбик & 99,4 & 0,0 & 99,8 & 74,1 & 8,1 & 0,0 & 54,7 \\
\hline Мьянма & 22,0 & 2,9 & 99,2 & 0,1 & 52,6 & 0,0 & 9,9 \\
\hline Непал & 39,0 & 0,0 & 100,0 & 0,5 & 99,5 & 0,4 & 4,5 \\
\hline Нигер & 83,2 & & 98,9 & 0,0 & 95,3 & 0,0 & 96,9 \\
\hline Руанда & 100,0 & 93,9 & 100,0 & & 70,6 & 0,0 & 99,6 \\
\hline Самоа & 4,0 & 0,0 & 98,1 & 0,0 & 89,7 & 0,0 & 91,1 \\
\hline $\begin{array}{l}\text { Сан-Томе и } \\
\text { Принсипи }\end{array}$ & 100,0 & & 100,0 & & 24,5 & 0,0 & 97,2 \\
\hline Сенегал & 5,4 & 0,0 & 98,5 & 10,4 & 8,1 & 0,0 & 90,8 \\
\hline Сьерра Леоне & 95,6 & 0,0 & 99,9 & 0,0 & 22,7 & 0,0 & 88,7 \\
\hline $\begin{array}{l}\text { Соломоновы } \\
\text { острова }\end{array}$ & 100,0 & 0,0 & 100,0 & 0,0 & 58,3 & 0,0 & 99,6 \\
\hline Сомали & 100,0 & 0,0 & 99,8 & 68,9 & 7,9 & 0,0 & 98,0 \\
\hline Судан & 100,0 & 0,0 & 97,1 & 10,0 & 7,8 & 0,0 & 95,9 \\
\hline Танзания & 94,5 & 0,6 & 100,0 & 78,8 & 82,6 & 0,0 & 91,2 \\
\hline Того & 94,4 & 0,0 & 98,6 & 0,0 & 100,0 & 0,0 & 99,1 \\
\hline Тувалу & & & 100,0 & & & & 0,0 \\
\hline Уганда & 99,7 & 0,0 & 99,1 & 6,1 & 46,4 & 0,0 & 99,9 \\
\hline Вануату & 100,0 & 0,0 & 99,9 & 0,0 & 43,9 & 0,0 & 100,0 \\
\hline Йемен & 100,0 & 0,0 & 100,0 & 0,4 & 5,8 & 0,0 & 100,0 \\
\hline Замбия & 99,6 & 17,0 & 98,8 & 0,0 & 100,0 & 0,0 & 96,8 \\
\hline В среднем НРС & 37,9 & 0,5 & 99,7 & 16,7 & 47,6 & 2,2 & 52,9 \\
\hline \multicolumn{8}{|c|}{$\begin{array}{l}\text { Примечания. 1. По Индии и Корее - представлены данные за } 1999 \text { г. } \\
\text { 2. Не содержит позиций с зарегистрированной торговлей. }\end{array}$} \\
\hline
\end{tabular}

Источник: WITS. 
Таблица 11

\section{Показатель отношения беспошлинного импорта к общему импорту торгового партнера в 2010 г., \%}

\begin{tabular}{|c|c|c|c|c|c|c|c|}
\hline HPC & Канада & Китай & EC & Индия & Япония & Корея & США \\
\hline Афганистан & 100,0 & 11,0 & 27,4 & & 96,5 & 44,8 & 75,7 \\
\hline Ангола & 100,0 & 99,8 & 96,7 & & 100,0 & 13,2 & 100,0 \\
\hline Бангладеш & 100,0 & 30,3 & 99,3 & & 100,0 & 32,9 & 3,7 \\
\hline Бенин & 100,0 & 56,4 & 97,4 & & 100,0 & 100,0 & 98,2 \\
\hline Бутан & 100,0 & 100,0 & 70,4 & 100,0 & 100,0 & 3,2 & 99,7 \\
\hline Буркина Фасо & 100,0 & 3,6 & 96,3 & & 100,0 & 48,4 & 85,3 \\
\hline Бурунди & 100,0 & 100,0 & 100,0 & & 100,0 & 100,0 & 100,0 \\
\hline Камбоджа & 100,0 & 59,4 & 98,6 & & 99,3 & 85,8 & 1,1 \\
\hline $\begin{array}{l}\text { Центрально- } \\
\text { африканская } \\
\text { Республика }\end{array}$ & 100,0 & 100,0 & 94,0 & & 100,0 & 100,0 & 100,0 \\
\hline Чад & 100,0 & 99,5 & 99,8 & & 100,0 & 100,0 & 100,0 \\
\hline Коморские острова & 100,0 & 4,7 & 100,0 & & 0,0 & 88,3 & 100,0 \\
\hline $\begin{array}{l}\text { Демократическая } \\
\text { Республика Конго }\end{array}$ & 100,0 & 81,3 & 86,9 & & 100,0 & 100,0 & 99,9 \\
\hline Джибути & 100,0 & 95,0 & 94,0 & & & 100,0 & 100,0 \\
\hline Восточный Тимор & 99,6 & 66,4 & 99,7 & & 100,0 & 0,6 & \\
\hline $\begin{array}{l}\text { Экваториальная } \\
\text { Гвинея }\end{array}$ & 100,0 & 100,0 & 99,2 & & 100,0 & 100,0 & 100,0 \\
\hline Эритрея & 72,2 & 81,0 & 78,3 & & 100,0 & 100,0 & 95,5 \\
\hline $\begin{array}{l}\text { Эфиопия (без } \\
\text { Эритреи) }\end{array}$ & 99,7 & 95,9 & 92,1 & 28,3 & 92,6 & 35,8 & 99,9 \\
\hline Гамбия & 100,0 & 99,9 & 91,6 & & 100,0 & 100,0 & 98,8 \\
\hline Гвинея & 100,0 & 98,8 & 99,6 & & 11,5 & 0,9 & 100,0 \\
\hline Гвинея Биссау & 100,0 & 99,7 & 97,1 & & & 5,8 & 100,0 \\
\hline Гаити & 100,0 & 28,8 & 100,0 & & 100,0 & 70,2 & 6,1 \\
\hline Кирибати & 100,0 & 99,6 & 42,6 & & 100,0 & 96,0 & 100,0 \\
\hline Лаос & 100,0 & 92,4 & 99,4 & & 90,1 & 99,5 & 7,3 \\
\hline Лесото & 100,0 & 21,2 & 100,0 & & 100,0 & 94,2 & 100,0 \\
\hline Либерия & 100,0 & 80,1 & 51,0 & & 8,4 & 91,5 & 97,1 \\
\hline Мадагаскар & 100,0 & 90,9 & 100,0 & 2,0 & 99,9 & 65,0 & 99,7 \\
\hline
\end{tabular}


Таблица 11 (окончание)

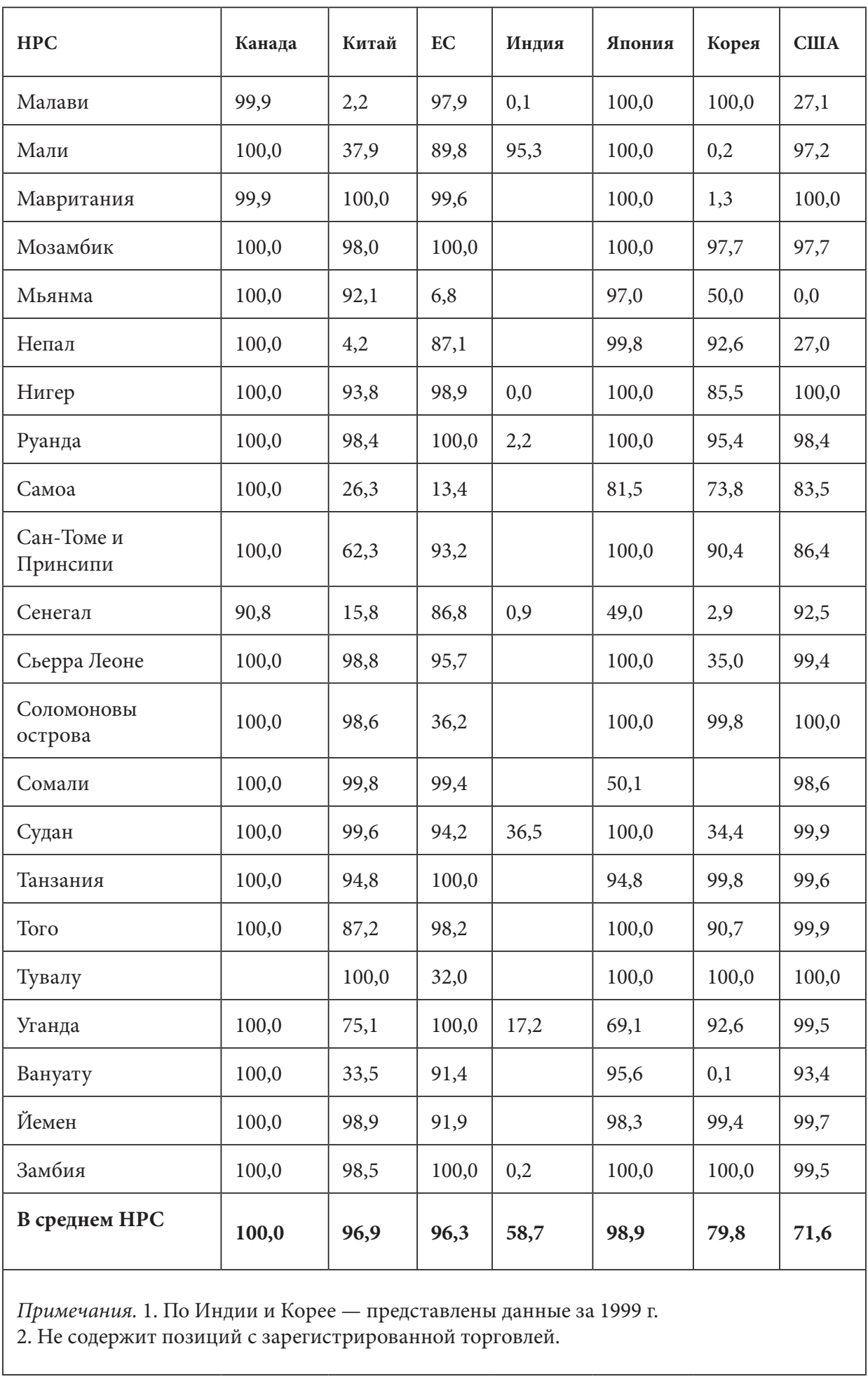

Источник: WITS. 
Литература

[1] Kravis I.B. Trade as a handmaiden of growth: Similarities between the nineteenth and twentieth centuries // Economic Journal. 1970. Vol. 80. P. $850-872$.

[2] Nurske R. Balanced and unbalanced growth / R. Nurske, G. Haberler, R.M. Stern (eds.). Equilibrium and Growth in the World Economy // Harvard Economic Studies. 1961. Vol. 118.

[3] UNCTAD. UNCTAD's Appraisal of the Implementation of the Brussels Programme of Action for LDCs for the Decade 2001-2010 (document No. UNCTAD/ALDC, 2009/2). Geneva, New York: United Nations, 2010.

[4] WTO. Market access for products and services of export interest to Least-developed Countries, Note by the Secretariat (WTO document WT/COMTD/LDC/W/51/Rev.1, 10 October 2011).

\section{Laird S. ${ }^{1}$}

\section{A Review of Trade Preference Schemes for the World's Poorest Countries}

This study analyses the implementation of preferential trade schemes in favor of LDCs to provide their trade and development in respect preferential access of LDCs to seven major markets (Canada, China, European Union, India, Korea, Japan, and the United States). The impact of preferential schemes on LDS's trade is analyzed not only in respect of trade of particular countries but also in respect of its application to commodity groups and exemptions within different preferential schemes. Possible improvements and consequences of Doha Round negotiations for LCD's preferential schemes are discussed. Some proposals aimed at more contribution of preferential schemes to economic development of LDCs are suggested.

Key worlds: $L D C$, trade preferences, duty-free and quota-free market access (DFQF), aid to development.

\section{(Окончание следует)}

1 Laird Sam - ICTSD Programme on Competitiveness and Development. 